\title{
Should Consumers be Permitted to Waive Products Liability? Product Safety, Private Contracts, and Adverse Selection
}

\section{Citation}

Albert Choi and Kathryn E. Spier, Should Consumers be Permitted to Waive Products Liability? Product Safety, Private Contracts, and Adverse Selection, 30 J. Law Econ. Organ. 734 (2014).

\section{Published Version}

http://jleo.oxfordjournals.org/content/30/4/734.full.pdf+html

\section{Permanent link}

http://nrs.harvard.edu/urn-3:HUL.InstRepos:30012795

\section{Terms of Use}

This article was downloaded from Harvard University's DASH repository, and is made available under the terms and conditions applicable to Open Access Policy Articles, as set forth at http:// nrs.harvard.edu/urn-3:HUL.InstRepos:dash.current.terms-of-use\#OAP

\section{Share Your Story}

The Harvard community has made this article openly available. Please share how this access benefits you. Submit a story.

Accessibility 


\title{
HARVARD
}

JOHN M. OLIN CENTER FOR LAW, ECONOMICS, AND BUSINESS

\author{
SHOULD CONSUMERS BE \\ PERMITTED TO WAIVE PRODUCTS \\ LIABILITY? PRODUCT SAFETY, PRIVATE \\ CONTRACTS AND ADVERSE SELECTION
}

Albert Choi and Kathryn E. Spier

Discussion Paper No. 680

$09 / 2010$

Harvard Law School

Cambridge, MA 02138

This paper can be downloaded without charge from:

The Harvard John M. Olin Discussion Paper Series:

http://www.law.harvard.edu/programs/olin_center/

The Social Science Research Network Electronic Paper Collection: http://ssrn.com/ 


\title{
Should Consumers be Permitted to Waive Products Liability? Product Safety, Private Contracts, and Adverse Selection*
}

\author{
Albert Choi \\ University of Virginia Law School \\ Kathryn Spier \\ Harvard Law School
}

September 21, 2010

\begin{abstract}
A potentially dangerous product is supplied by a competitive market. The likelihood of a product-related accident depends on the unobservable precautions taken by the manufacturer and on the type of the consumer. Contracts include the price to be paid by the consumer ex ante and stipulated damages to be paid by the manufacturer ex post in the event of an accident. Although the stipulated damage payments are a potential solution to the moral hazard problem, firms have a private incentive to reduce the stipulated damages (and simultaneously lower the up front price) in order to attract the safer consumers who are less costly to serve. The competitive equilibrium - if an equilibrium exists at all-features suboptimally low stipulated damages and correspondingly suboptimal levels of product safety. Imposing tort liability on manufacturers for uncovered accident losses — and prohibiting private parties from waiving that liabilitycan improve social welfare.
\end{abstract}

\section{Introduction}

In the summer of 1980, Joseph Mullan was injured when his home-built airplane crashed on the runway at the Loveland-Fort Collins, Colorado airport. Mr. Mullan sued Quickie Aircraft Corporation, the manufacturer and distributor of the kit from which he had built the plane. ${ }^{1}$ A central issue in the case was a waiver-of-liability clause in the kit's sales

${ }^{*}$ The authors thank Jim Dana, Steve Shavell, Abe Wickelgren, and 2010 summer workshop participants at University of Virginia Law School for many helpful comments and suggestions. Comments are welcome to ahc4p@virginia.edu or kspier@law.harvard.edu.

${ }^{1}$ Mullan v. Quickie Aircraft Corp., 797 F.2d 845 (10th Cir. 1986). 
contract, a clause intended to insulate Quickie from liability for future damages. ${ }^{2}$ A lower court deemed the clause to be unconscionable, and the jury subsequently found Quickie liable for $\$ 155,000$ in damages. Quickie appealed the lower court's decision, contending that the waiver-of-liability clause was, in fact, a valid agreement between sophisticated parties. Mr. Mullan was no novice: he was an FAA certified pilot and had commercial experience making airplane propellers. Moreover, Mr. Mullan had been actively involved in the drafting of the sales contract, modifying and fine-tuning the contractual clauses originally proposed by Quickie. The Tenth Circuit court found that Mullan had indeed had a reasonable opportunity to read and understand the waiver-of-liability clause in the sales contract, and the case was subsequently remanded to the district court for further consideration. $^{3}$ The question of whether consumers like Mr. Mullan should be permitted to waive products liability remained unanswered. ${ }^{4}$

Should manufacturers and sophisticated consumers be free to design their own liability schemes for defective products? This paper argues that the answer may be "No." Free markets - even those involving fully rational consumers - may fail to operate efficiently when product safety is not directly observed by consumers at the time of purchase. Manufacturers certainly do have private incentives to issue warranties, stipulated damage provisions, and product-specific insurance policies in order to signal the safety of their products. Distortions emerge, however, when consumers vary in their likelihood of suffering harm and the market cannot engage in first-degree price discrimination. In order to obtain lower prices for the products they buy, rational low-risk consumers may be willing to waive their rights to be compensated ex post. They would do this knowing full well that the lack of manufacturer accountability will compromise the safety of the products that they consume.

Formally, we consider a model where a potentially dangerous product is supplied by a competitive market. There is a moral hazard problem in the sense that the likelihood of a product-related accident depends, in part, on the unobservable safety precautions taken by

\footnotetext{
${ }^{2}$ Specifically, the contract provided that "Quickie Aircraft Corporation is not responsible, and makes no warranties, express or implied whatsoever, regarding the structural integrity, performance, flight characteristics, or safety of the Buyer's completed air craft and its component parts....Buyer expressly waives any and all claims arising from structural integrity, performance, flight characteristics, mechanical failures, and risks of flying a home-built aircraft." Mullan, 797 F.2d at 848. These clauses are also referred to as exculpatory clauses, exclusion clauses, assumption-of-risk clauses, hold-harmless clauses, and limitation-of-liability clauses.

${ }^{3}$ The court states: "[g]iven Mullan's expertise with respect to airplanes, his ability with woodworking, his awareness of the recreational nature of a home-built aircraft, his thorough investigation of the Quickie aircraft prior to ordering it, his modification of the sales agreement, coupled with all of the circumstances surrounding the formation of the contract, we do not view the disclaimer provision as unconscionable." Mullan, 797 F.2d at 852 .

${ }^{4}$ On the question of whether exculpatory clauses should be upheld, the court relied on Colorado Supreme Court's decision of Jones v. Dressel, 623 P.2d 370 (Colo. 1981). In that case, the Supreme Court identified four factors that must be considered: "(1) the existence of a duty to the public; (2) the nature of the service performed; (3) whether the contract was fairly entered into; and (4) whether the intention of the parties is expressed in clear and unambiguous language." Id. at 376. The Mullan court stated that "Quickie did not owe a duty to the public...." Mullan, 797 F.2d at 853.
} 
manufacturers. There is also an adverse selection problem in the sense that some consumers are intrinsically more accident prone than others, and consumers are privately informed about their probability of being harmed. Manufacturers compete for consumers by offering contracts that specify (1) the price to be paid by the consumer to the manufacturer up front, and (2) stipulated damages to be paid by the manufacturer to the consumer ex post in the event of an accident.

We show that the unregulated private market will under-supply product safety. If the stipulated damages fully covered the losses to consumers, the manufacturers would have an incentive to choose socially optimal precautions. But when fully insured against future losses, consumers would disregard their own risk types when making their purchase decisions. They would buy on the basis of price alone and would be pooled together from the perspective of the manufacturers. Low-risk consumers, who are cheaper to serve, would effectively subsidize their high-risk counterparts. In this environment, firms would have an incentive to reduce the stipulated damages and lower the up front price in order to attract only the low-risk consumers. Because of this adverse selection problem, the competitive equilibrium - if an equilibrium exists at all — features suboptimally low stipulated damages and correspondingly suboptimal levels of product safety. ${ }^{5}$ We show that imposing tort liability on manufacturers for uncovered accident losses - and prohibiting private parties from waiving that liability-improves social welfare.

Currently, in the United States, both the tort and contract laws are hostile towards private contractual limitations of liability. Under the products liability law, when a consumer suffers injury from a "defective" product,${ }^{6}$ notwithstanding any contractual waiver, the consumer can still bring a liability claim against the manufacturer. The Restatement (Third) of Torts: Products Liability $\S 18$ (1998) states that "[d]isclaimers and limitations of remedies by product sellers or other distributors, waivers by product purchasers, and other similar contractual exculpations, oral or written, do not bar or reduce otherwise valid products liability claims against sellers or other distributors of new products for harm to persons." 7 The contract law is similarly hostile towards manufacturers limiting liability

\footnotetext{
${ }^{5}$ The basic structure of our argument is similar to Rothschild and Stiglitz's (1976) analysis of insurance markets. In their model, the need for insurance is driven by the risk aversion of consumers. In our model consumers are risk neutral, but liability is necessary to create incentives for the manufacturers to take precautions. Our model also has the added complexity that the social planner would like to discourage the highest risk consumers from purchasing the product at all. As a result, the optimal social policy may involve less-than-full coverage for accident losses. See also Riley (1976) and Wilson (1977).

${ }^{6}$ A defect can stem from three possible sources: design, manufacturing, or warning. As a rough generalization, while manufacturing defects are said to impose strict (or even absolute) liability on the manufacturerplaintiff only needs to show that the product did not conform to the defendant's specifications not whether the defendant was negligent in production, design and warning defects require a proof of manufacturer's negligence or fault. See Schwartz (1988), Priest (1991), and Abraham (1997).

${ }^{7}$ The seminal case that supports this rule is Henningsen v.Bloomfield Motors, Inc., 32 N.J. 358, 161 A.2d 69 (1960). In that case, plaintiff was injured when the steering wheel of a new Plymouth failed. Even though the contract contained a disclaimer of liability for personal injury, the court invalidated the clause. An exception to this principle is in negligence law, where waivers of liability are commonly upheld. In cases
} 
for personal ("non-commercial") injury. ${ }^{8}$ The Uniform Commercial Code $§ 2-719(3)$ states that "[1]imitation of consequential damages for injury to the person in the case of consumer goods is prima facie unconscionable but limitation of damages where the loss is commercial is not."

While the case for imposing tort liability on manufacturers for the harms caused to bystanders and other non-contractual victims is well-established in the theoretical law and economics literature, the case for extending tort liability to the harms borne by consumers (and other contractual victims) is considerably weaker. ${ }^{9}$ Manufacturer liability would be unnecessary when the safety of the product is easily observed (and well understood) by consumers at the time of sale, since consumers would demand cost-justified improvements in product safety and would be willing to pay a premium for them (Hamada, 1976). ${ }^{10}$ Manufacturer liability may be socially desirable when consumers systematically underestimate product risks; without it, the market will tend to under-provide safety. This argument was first made by Spence (1977), and has been advanced by many others. ${ }^{11}$ Manufacturer liability may also be desirable when the safety of products is not readily observable to consumers at the time of sale, since liability provides incentives for better product design. ${ }^{12}$ However, in order to use this argument to justify products liability laws, one must first explain the failure of market participants to find private solutions to moral hazard and

involving recreational activities such as sky diving, bungee jumping, and snowmobiling, providers of these activities may successfully avoid liability for consumer harms. See Ausness (2000).

${ }^{8}$ The US Supreme Court, in East River Steamship Corp. v. Transamerica Delaval, Inc., 476 U.S. 858 (1986), stated that when injury is commercial, affecting only the product, the issue of liability is left to the law of contracts.

${ }^{9}$ Polinsky and Shavell (2010) argue that, at least with respect to products that are sold widely in the market, market forces are strong as to provide the manufacturers with better deterrence incentive than the current, costly product liability system. Many legal scholars have emphasized that allowing manufacturers and consumers to design their own liability schemes, through contract, will enhance social welfare by allowing them to shift product-related risks to those who can bear them at a lower cost. See Ausness (2000), Schwartz (1988), and Priest (1981, 1991).

${ }^{10} \mathrm{Oi}$ (1973) showed that products liability could lead to strictly worse market outcomes if consumers were heterogeneous in the value that the value that they placed on product safety and price discrimination was impossible. By forcing complete coverage of consumer losses, manufacturers lose the ability to screen among consumers and fine-tune product safety to a particular consumer's needs.

${ }^{11}$ See also Epple and Raviv (1978); Polinsky and Rogerson (1983); Geistfeld (1995); Schwartz (1988, 1992). In our model, even though consumers correctly perceive product safety, due to the problems of adverse selection, low-risk consumers have an incentive to accept suboptimal warranty and lower price, which, in turn, produces suboptimal deterrence incentive to the manfuacturers. Absent consumer misperceptions of risk, products liability may also be desirable when consumers cause harm to bystanders when using the products, and the consumers are themselves judgment proof (Hay and Spier, 2005). Related work on vicarious liability includes Sykes (1998) and Dari Mattiacci and Parisi (2002).

${ }^{12}$ Absent financial incentives, manufacturers would be tempted to chisel quality to save money and would decline to disclose product defects to consumers. Daughety and Reinganum (1995) argue that liability facilitates the signaling of product quality through the prices charged by manufacturers. They also suggest that welfare could be further improved through the regulation of safety standards. Daughety and Reinganum (1997) formally model penalties for lying about product safety and quality. See also Daughety and Reinganum (2008). None of these papers consider product warranties or private contractual solutions. 
adverse selection problems. ${ }^{13}$ In order to establish the social value of tort liability, it is therefore crucial to understand why private contracts for dangerous products may fail to operate efficiently.

There is a small literature arguing that private contracts between sophisticated parties may not lead to efficient levels of product safety. ${ }^{14}$ In an adverse-selection model with heterogeneous, risk-averse consumers, Ordover (1979) argues that products liability can help overcome the inefficiencies of private insurance markets. He assumes that product safety is observable to consumers at the time of sale, and does not consider the problem of manufacturer moral hazard. Also, in contrast to our results, due to the failure of the insurance market, the product market, in equilibrium, will provide excessively safe products. ${ }^{15}$ Wickelgren (2009) argues that the failure of private contracting stems from the transactions costs of using the legal system to resolve tort disputes. Because of the ex post costs of using the legal system to compensate victims of accidents, consumers will have a private incentive to waive liability in exchange for a lower purchase price, not internalizing the negative implications for ex ante safety design. In his setting, mandating liability is a commitment device that induces higher (and more efficient) ex ante investments in product safety. ${ }^{16}$ Arlen and MacLeod (2003) apply a similar logic to waivers of liability for medical malpractice. $^{17}$

The economics literature has proposed a number of different rationales for product warranties but has largely side-stepped the normative issues surrounding their use (namely the optimal scope for policy interventions such as tort liability). ${ }^{18}$ Warranties can solve

\footnotetext{
${ }^{13}$ Note that tort liability may also be desirable when the transactions costs associated with the drafting of private contracts is prohibitively high. See Schwartz (1988). Even absent private contracts and warranties, however, liability may be unnecessary in dynamic settings if manufactures can credibly establish reputations for high quality. See Klein and Leffler (1981).

${ }^{14}$ There is also a small literature arguing that privately stipulated damages can be used by incumbent monopolists for anticompetitive purposes. See Aghion and Bolton (1987) and Spier and Whinston (1995). In these models, the stipulated damages are excessive rather than being insufficient.

${ }^{15}$ Rather than serving the function of encouraging greater investments by the manufacturer in product safety, products liability helps to mitigate the social losses associated with consumer risk aversion. As in Rothschild and Stiglitz (1976), Ordover shows that a competitive equilibrium for insurance either does not exist or, when it does, consumers purchase incomplete insurance coverage.

${ }^{16}$ Wickelgren (2009) builds upon the insights of Fudenberg and Tirole (1990), where the ex post renegotiation of agency contracts undermines the ex ante incentives. See also Spier (1997).

${ }^{17}$ There, doctors can improve the quality of care by investing in their human capital ex ante. Ex post, patients have an incentive to waive tort liability, not taking into account the negative impact their actions will have on the doctor's ex ante incentives. Arlen (2010) argues that further market failures stem from collective action problems and adverse selection.

${ }^{18}$ Priest (1981) describes informally how consumer heterogeneity may lead to inefficiencies, as the premium charged to consumers would reflect the average risk to consumers rather than the consumer-specific risk. He also describes how manufactures will offer less-than-full warranties in this setting to combat the consumer adverse selection problem. Id. at 1317. He concludes, however, that judicial expansion to warranty or tort liability will make matters worse instead of better. Id. at 1349-1351. Intervention may be desirable when consumers misperceive risks (Priest, 1981; Schwartz, 1988) or when risks are difficult for consumers to foresee (Kessler, 1943). See also Priest (1991).
} 
the "market for lemons" problem when sellers have superior information about the quality of their products (Akerlof, 1970), allowing sellers of high quality products to credibly signal their types (Grossman, 1983). Second, warranties can be an optimal contractual response to producer moral hazard. The warranty effectively creates a "performance bond," generating incentives for the manufacturer to make investments in product quality and safety (Priest, 1981; Cooper and Ross, 1985; Dybvig and Lutz, 1993). ${ }^{19}$ Interestingly, product warranties may also be offered by manufactures when the quality of the product is fully observable at the time of sale. Manufacturers may bundle warranties with the sale of the products when consumers are risk averse and the market for third-party insurance is thin (Brown, 1974; Heal, 1977). Moreover, product warranties can be used as a price-discrimination device to screen among heterogeneous consumers (Kubo, 1986; Padmanabhan, 1995; Matthews and Moore, 1987).

The paper is structured as follows. Section 2 presents the general setup and timing of the model. Section 3 establishes a benchmark where the social planner can design the contracts offered on the market, but the firms remain free to choose their precautions and consumers are free to choose whether or not to purchase the product. Section 4 characterizes the competitive equilibrium and shows that the social optimum is not obtained. Competitive firms offer less than full warranties and correspondingly suboptimal product safety features. Section 5 considers the public policy response to this problem. The social planner, who has control over the liability policy, can increase welfare by mandating higher levels of warranty coverage. Section 6 concludes.

\section{The Setup}

There is a unit mass of consumers, indexed by the preference type $\tilde{\theta} \in\left\{\theta_{H}, \theta_{L}\right\}$, with $1>\theta_{H}>\theta_{L}>0$. We will often refer to type $\theta_{H}$ as the high-risk type, and $\theta_{L}$ as the low-risk type. The probability that any given consumer is of type $\theta_{H}$ is $\pi \in(0,1)$ and the probability that she is of type $\theta_{L}$ is $1-\pi$. Let $\bar{\theta} \equiv \pi \theta_{H}+(1-\pi) \theta_{L}$. Each consumer derives a gross valuation of $v$ from using the product and, in case there is an accident, she will suffer a harm of $h .^{20}$ The probability that the product will cause an accident depends on both consumer's type (the propensity for accidents) and the amount of unobservable precaution taken by the manufacturer. More specifically, the probability of an accident for a consumer of type $\theta_{i}$ is given by $q\left(\theta_{i}, e\right)=\theta_{i}-e$, where $e \in\left[0, \theta_{L}\right)$ stands for the amount of unobservable effort or precaution taken by the manufacturer for each purchasing

\footnotetext{
${ }^{19}$ Product warranties will typically be less than full if there is a consumer moral hazard problem. See Lutz and Padmanabhan (1995) for consumer moral hazard in an insurance model, and Lutz and Padmanabhan (1998) for a two-sided moral hazard model.

${ }^{20}$ The size of the harm $h$ can be either fixed or in expectation, so that the actual harm may vary among consumers. Either assumption will produce the same substantive results. Also, $h$ can contain both pecuniary and non-pecuniary, e.g., pain and suffering, elements.
} 
consumer. $^{21}$ The manufacturer's unit cost of production is assumed to be $c(e)$ where $c^{\prime}(0)=0, c^{\prime}(e)>0, c^{\prime \prime}(e) \geq 0$, and $\lim _{e \rightarrow \theta_{L}} c(e)=\infty$. We normalize the fixed costs of production to be zero.

Each manufacturer can offer a contract $(p, w)$ where $p$ stands for the price of the product and $w$ is the warranty or stipulated damages that the manufacturer will pay to the consumer in the event that the consumer suffers harm of $h$. When a consumer of type $\theta_{i}$ chooses $(p, w)$ in which the manufacturer has exerted a precaution of $e$, the consumer's (expected) utility is $v-p-q\left(\theta_{i}, e\right)(h-w)$ and the manufacturer's (expected) profit is $p-c(e)-q\left(\theta_{i}, e\right) w .^{22}$ If the consumer does not purchase any product, we assume that she realizes zero utility (her reservation value). We will consider two possible market structures for producers: monopoly production with a single firm and a competitive market with free entry.

The timing of the game is as follows. At time $t=1$, consumers privately learn their types. At time $t=2$, firms simultaneously offer contracts $(p, w)$ and choose their precaution levels $e .^{23}$ Although the firms do not observe the consumers' types directly, they offer contracts with expectations of which type(s) of consumers the contracts will later attract. At time $t=3$, each consumer observes all contracts that are offered in the market, and chooses which firm to purchase from (if any). If a consumer decides to make a purchase, she pays the price $p$ as specified in the contract. Consumers do not observe the firms' precautions, but they make an inference based on the contract, in particular the warranty, offered. At time $t=4$, purchasing consumers derive a gross utility of $v$ and accidents occur with probability $q\left(\theta_{i}, e\right)$. When an accident occurs, warranty payments $(w)$ are made by the firms to the consumers who have suffered harm.

\section{A Social Welfare Benchmark}

Social welfare depends on two factors: the level of precautions taken by the firms and the type(s) of consumers that purchase the products. Conditional on type $\theta_{i}$ consumer

\footnotetext{
${ }^{21}$ Because the amount of precaution $(e)$ taken by the manufacturer is not observable, imposing a liability regime that conditions recovery on a negligence principle, i.e., when $e$ falls below some threshold $\bar{e}$, is not feasible. If the manufacturer's precaution is observable by court without any error, the first best can be achieved either through contract (which stipulates $e^{*}$ as a contractual obligation) or through mandatory imposition of the negligence standard that sets the standard at $e^{*}$. Manufacturer's liability will be discontinuous at $e^{*}$. If precaution can be observed only with error, on the other hand, even with the negligence standard, manufacturer's liability will no longer be discontinuous and much of the analysis in this paper will carry over.

${ }^{22}$ We have assumed, for the ease of exposition, that the consumers' gross valuations $(v)$ are identical across types, but this can be relaxed. Even if the gross valuations were different $\left(v_{H} \neq v_{L}\right)$, so long as $v_{L}-\theta_{L} h \geq v_{H}-\theta_{H} h$, the low-risk consumers remain the more "efficient" type (i.e., type with a higher surplus), and the main results, that (1) unregulated market will produce under-deterrence and (2) mandating a higher level of (perhaps full) warranty can induce a better equilibrium, will remain unchanged.

${ }^{23}$ By letting the manufacturers offer contracts and choose the precaution levels simultaneously, we eliminate the potential commitment and signaling problems.
} 
purchasing the product, the precaution level $e_{i}$ should be chosen to maximize the social surplus associated with that consumer type,

$$
v-\left(\theta_{i}-e_{i}\right) h-c\left(e_{i}\right) .
$$

This produces the first-order condition of

$$
c^{\prime}\left(e_{i}\right)=h
$$

Due to additive separability on the probability of accident, the socially optimal level of precaution is independent of the consumer type $(\theta)$. Let $e^{*}$ denote the first-best level. More generally, with the assumptions on $c$, the first-order condition of $c^{\prime}(e)=w$ produces an implicit function of $e(w)$ where $e^{\prime}(w)>0$ and $e(h)=e^{*}>0$.

With the firms choosing the first-best level of precaution $\left(e^{*}\right)$, the social surplus associated with a consumer of type $\theta_{i}$ using the product is $v-\left(\theta_{i}-e^{*}\right) h-c\left(e^{*}\right)$. It is socially efficient for a consumer to purchase the product when $v>\left(\theta_{i}-e^{*}\right) h+c\left(e^{*}\right)$. We will consider two cases. In case $1, v \geq\left(\theta_{H}-e^{*}\right) h+c\left(e^{*}\right)>\left(\theta_{L}-e^{*}\right) h+c\left(e^{*}\right)$ and it is socially efficient for both types of consumer to be served. In case 2 , on the other hand, $\left(\theta_{H}-e^{*}\right) h+c\left(e^{*}\right)>v>\left(\theta_{L}-e^{*}\right) h+c\left(e^{*}\right)$, so it is socially efficient for only the low-risk consumers to be served. ${ }^{24}$

Suppose that the social planner can dictate both the price and the warranty terms of the manufacturers' contracts. The social planner cannot directly control the consumers' purchase decisions, the manufacturers' precaution levels, or the decision of the manufacturers whether to participate in the market. The following proposition establishes that the social planner can implement the first-best market outcome through the proper choice of $p$ and $w$.

Proposition 1 When it is efficient to serve both types of consumer with the optimal precaution (case 1), the social optimum is implemented with $p \in\left[\left(\bar{\theta}-e^{*}\right) h+c\left(e^{*}\right), v\right]$ and $w=h$. Both types of consumer purchase the product, and the manufacturers take optimal precautions $e^{*}$ and earn non-negative profits. When it is efficient to serve only the low type of consumer with the optimal precaution (case 2), the social optimum is implemented with $p=v$ and $w=h$. The low-risk consumers purchase the product and the high-risk consumers do not, and the manufacturers take optimal precautions $e^{*}$ and earn strictly positive profits.

By forcing the manufacturers to offer a full warranty $(w=h)$, the social planner gives the manufacturers the incentive to choose the first-best level of precaution $\left(e^{*}\right)$. Since

\footnotetext{
${ }^{24}$ There is a third case where $v<\left(\theta_{L}-e^{*}\right) h+c\left(e^{*}\right)$ and it is socially efficient for neither type of consumer to purchase the product. This case is uninteresting, because there will never exist an equilibrium where the product is actually sold.
} 
consumers are fully indemnified against accident losses, they strictly prefer to purchase the product whenever $p<v$ and are indifferent about purchasing it when $p=v$. Setting $p \in\left[\left(\bar{\theta}-e^{*}\right) h+c\left(e^{*}\right), v\right]$ implements the first-best outcome in case 1 because both consumer types are willing to purchase the product and the firms at least break even. In case 2, since $p=v$, both consumer types are indifferent between purchasing the product and not purchasing it. It is therefore an equilibrium for the low-risk consumers to purchase the product and the high-risk consumers to forego it, as required for social optimality in case 2 .

Note that the first-best outcome for case 2 can be implemented arbitrarily closely in dominant strategies by carefully choosing a warranty slightly below $h$ and a corresponding price slightly below $v$. These values must be chosen so that the low-risk consumers strictly prefer to purchase the product and the high-risk consumers strictly prefer to forego it. Formally, let $w(\Delta)=h-\Delta$ and $p(\Delta)=v-\Delta(\bar{\theta}-e(w(\Delta)))$ where $e(w(\Delta))$ is the implicit solution to $c^{\prime}(e(w(\Delta)))=w(\Delta){ }^{25}$ Note that $e(\Delta)<e^{*}$ and approaches $e^{*}$ in the limit as $\Delta$ approaches zero, and $p(\Delta)<v$ and approaches $v$ in the limit as $\Delta$ approaches zero. A consumer of type $\theta_{i}$ will strictly prefer to purchase the product when

$$
v-\left[\theta_{i}-e(w(\Delta))\right][h-w(\Delta)]-p(\Delta)>0 .
$$

Substituting for $w(\Delta)$ and $p(\Delta)$ and rearranging terms, this becomes $\theta_{i}<\bar{\theta}$. This is clearly satisfied when $\theta_{i}=\theta_{L}$ but not when $\theta_{i}=\theta_{H}$.

It bears emphasizing that, in case 2 , social optimality requires that both consumer types to be indifferent between purchasing and not purchasing the product $(p=v)$, or at least that the price to be arbitrarily close to the consumers' gross valuation. The consumer surplus is (arbitrarily close to) zero in this case, and the manufacturers are earning all the rents from the transaction. In other words, maximizing social welfare is not necessarily consistent with the manufacturers earning zero profits.

Finally, in the current section, we have assumed that the social planner, while unable to dictate the level of precaution, can control both the price and the warranty terms in contracts. As a matter of comparison, when we analyze optimal social policy in subsequent sections, we will assume that the social planner can control only the warranty aspect of contracts by, for instance, either allowing or disallowing contractual waivers or requiring firms to offer a particular level of warranty.

\footnotetext{
${ }^{25}$ The expression for $p(\Delta)$ has a straightforward interpretation. It is the expected reduction in future compensation for the "average" consumer of type $\bar{\theta}$ when the warranty falls from $h$ to $h-\Delta$. $\Delta$ is the reduction in the level of the warranty, and $(\bar{\theta}-e(w(\Delta)))$ is the probabilty of an accident. Thus, $\Delta(\bar{\theta}-e(w(\Delta)))$ is the expected reduction in future compensation for the "average" consumer of type $\bar{\theta}$ when the warranty falls from $h$ to $h-\Delta$.
} 


\section{The Unregulated Market Outcome}

Suppose that many firms compete for customers by offering price-warranty combinations in an unregulated environment. Assume also that there is no cost of entering the market. ${ }^{26}$ Consumers observe all contracts that are offered in the market before choosing from whom to buy (if at all). Although consumers do not directly observe the level of precautions chosen by the firms at the time of sale, they do make rational inferences based on the offered contract. Similarly, firms choose the precaution level and the contract based on the type(s) of consumers they expect to attract. In equilibrium, both the consumers' and the firms' beliefs will be consistent with the actions taken by the other.

As a matter of comparison, suppose consumer types are observed by the firms and that the firms can discriminate in the contracts offered to the different types of consumers. In case 1, where both types of consumer should be served, the full-information equilibrium will be given by

$$
\left(p_{i}, w_{i}\right)=\left(\left(\theta_{i}-e^{*}\right) h+c\left(e^{*}\right), h\right) \forall i .
$$

That is, all firms will offer full warranties, $w_{i}=h$, choose the optimal level of precaution, $e=$ $e^{*}$, and offer type-dependent prices that allow them to just break even, $p_{i}=\left(\theta_{i}-e^{*}\right) h+c\left(e^{*}\right)$. Note that the high-risk consumers pay a higher price than the low-risk consumers in this full-information setting since it is more costly for firms to provide full insurance to the high-risk types. In case 2 , where only the low-risk consumers should purchase the product, the competitive firms will offer $\left(p_{L}, w_{L}\right)=\left(\left(\theta_{L}-e^{*}\right) h+c\left(e^{*}\right), h\right)$ to the low-risk consumers only. The high-risk consumers will not be given any meaningful option to purchase the product. When firms can observe consumer types, under perfect competition, both the social welfare and consumer surplus are maximized.

When firms cannot observe the consumer types, however, the full-information outcome is not sustainable. In case 1, with full warranty, both types of consumer would strictly prefer the contract intended for the low-risk consumers because it is cheaper: $p_{L}=\left(\theta_{L}-e^{*}\right) h+$ $c\left(e^{*}\right)<p_{H}=\left(\theta_{H}-e^{*}\right) h+c\left(e^{*}\right)$. Similarly, in case 2, firms would not be able to prevent the high-risk consumers from purchasing the product at the contractual terms intended for low-risk consumers, Both consumer types would realize a strictly positive surplus of $v-p_{L}$. When the high-risk consumers purchase the product at price $p_{L}$, however, the firms will make a loss. ${ }^{27}$

\footnotetext{
${ }^{26}$ We assume perfect competition with free entry for the sake of convenience. Even if entry is (prohibitively) costly, so long as there is a large number of firms $(n>>1)$ competing in the market by offering $\left(p_{i}, w_{i}\right)$ contracts to consumers, all the competitive equilibrium results will carry over.

${ }^{27}$ We have also analyzed the equilibrium under an alternate set of assumptions of (1) consumers being able to observe firms' choice of precaution while (2) firms being unable to observe consumer type. Under those assumptions, although firms will choose the optimal level of precaution, no warranty will be offered due to adverse selection. On the other hand, a monopolist will offer full warranty - to extract consumer surplus and choose the optimal level of precaution.
} 
It is also fairly straightforward to show that a competitive pooling equilibrium, under which all firms offer a single contract that serves both types of consumer, cannot exist. For such an equilibrium to exist and allow the firms to break even, firms would have to set price equal to the average cost of providing the warranty. With a price equal to the average cost, the low-risk consumers would be paying too much for full insurance while the high-risk consumers would be paying too little: low-risk consumers would be subsidizing the high-risk consumers. Once the firms recognized this, they would have an incentive to cream-skim the low-risk consumers, i.e., deviate from the pooling equilibrium, by offering a contract with less insurance but at a (substantially) lower price, and would make a strictly positive profit. Put differently, low-risk consumers would have an incentive to signal their types to the market by seeking a contract with a lower price and lower warranty. The following lemma states this result more formally.

Lemma 1 There does not exist a competitive equilibrium where all firms pool and offer a single contract $\left(p_{0}, w_{0}\right)$ that serves both types of consumer.

Proof. Suppose there exists a pooling equilibrium in which all firms offer $\left(p_{0}, w_{0}\right)$ and both types of consumer purchase the product. The level of precaution, $e_{0}$, would be implicitly defined by $c^{\prime}\left(e_{0}\right)=w_{0}$. Given free entry, in that equilibrium, we must have firms making zero profit, i.e., $p_{0}=\left(\bar{\theta}-e_{0}\right) w_{0}+c\left(e_{0}\right)$. Since both types of consumer must be willing to purchase the product at this price, the equilibrium contract must also satisfy $p_{0} \leq v-\left(\theta_{H}-e_{0}\right)\left(h-w_{0}\right)$.

Suppose $0<w_{0} \leq h$. Consider a contract $\left(p_{1}, w_{1}\right)$ such that $w_{1}=w_{0}-\varepsilon$ and $p_{1}=$ $p_{0}-\left(h-w_{0}\right)\left(e\left(w_{0}\right)-e\left(w_{1}\right)\right)-\varepsilon\left(\bar{\theta}-e\left(w_{1}\right)\right) . \quad p_{1}$ is constructed to reflect the marginal reduction in expected value for the "average" consumer of type $\bar{\theta}$ stemming from the lower warranty (since the warranty has fallen by $\varepsilon$ ). Note that that $p_{1}$ is strictly smaller than $p_{0}$ and approaches $p_{0}$ in the limit as $\varepsilon$ approaches zero. A consumer of type $\theta_{i}$ will strictly prefer $\left(p_{1}, w_{1}\right)$ to $\left(p_{0}, w_{0}\right)$ when $v-\left[\theta_{i}-e\left(w_{1}\right)\right]\left[h-w_{1}\right]-p_{1}>v-\left[\theta_{i}-e\left(w_{0}\right)\right]\left[h-w_{0}\right]-p_{0}$. Substituting for $\left(p_{1}, w_{1}\right)$, we find that this inequality is satisfied if and only if $\theta_{i}<\bar{\theta}$. Therefore, the low-risk consumers will strictly prefer $\left(p_{1}, w_{1}\right)$ while the high-risk consumers will strictly prefer $\left(p_{0}, w_{0}\right)$. Because $\left(\theta_{L}-e_{1}\right) w_{1}+c\left(e_{1}\right)<\left(\bar{\theta}-e_{0}\right) w_{0}+c\left(e_{0}\right)$, the deviating firm will make a strictly positive profit by selling to the low risk consumers only.

Now suppose that there is a pooling equilibrium where $w_{0}=0$. In this scenario, the effort level would equal zero so the price would be $p_{0}=c(0)$. Since both types of consumer purchase the product, it must be the case that $v-\theta_{L} h>v-\theta_{H} h \geq c(0)$. (Note that it is socially efficient for both types of consumer to be served, even with zero effort). We will show that a profitable deviation exists that attracts only the high-risk types. Consider a contract $\left(p_{2}, w_{2}\right)$ such that $w_{2}=\varepsilon$ and $p_{2}=c(0)+h e\left(w_{2}\right)+\varepsilon\left(\theta_{H}-e\left(w_{2}\right)\right)$. Note that $p_{2}$ reflects the increase in the expected utility of the high-risk consumer who receives the 
warranty $w_{2}=\varepsilon$ and rationally expects the firm's effort level to rise from 0 to $e\left(w_{2}\right)$. The high-risk consumers will weakly prefer $\left(p_{2}, w_{2}\right)$ to $\left(p_{0}, w_{0}\right)$ while the low-types will strictly prefer $\left(p_{0}, w_{0}\right)$. The expected profit from this deviation is $p_{2}-\left(\theta_{H}-e\left(w_{2}\right)\right) w_{2}-c\left(e\left(w_{2}\right)\right)$, or after substituting for $p_{2}$ and $w_{2}$, he( $\left.\varepsilon\right)-(c(e(\varepsilon))-c(0))$. This is strictly positive when $\varepsilon$ is small, since $c^{\prime}(0)=0$ by assumption. Since this deviation would be profitable, the pooling equilibrium $\left(p_{0}, w_{0}\right)$ cannot exist.

If a competitive equilibrium does exist, therefore, it must be a separating kind. In case 1 , in which both types of consumer should be served, a separating equilibrium would involve two different contracts, $\left(p_{H}, w_{H}\right)$ and $\left(p_{L}, w_{L}\right)$, where the low-risk consumers choose one contract and the high-risk consumers select the other. In case 2 , where the high-risk consumers should not purchase the product, there will be a single equilibrium contract $\left(p_{0}, w_{0}\right)$ that serves the low-risk consumers only while the high-risk consumers would (weakly) prefer not purchasing at all. To characterize these separating competitive equilibria in detail, we examine the two cases separately.

\subsection{Case 1: Both Types of Consumer Should Purchase the Product}

Suppose $v \geq\left(\theta_{H}-e^{*}\right) h+c\left(e^{*}\right)>\left(\theta_{L}-e^{*}\right) h+c\left(e^{*}\right)$, so that it is socially efficient for both types of consumer to be served by the market with full warranty and precaution level $e^{*}$. We have already established that a pooling equilibrium does not exist. Suppose there is a competitive, separating equilibrium in which high-risk consumers choose $\left(p_{H}, w_{H}\right)$, low-risk consumers choose $\left(p_{L}, w_{L}\right)$, and firms choose precaution levels in accordance, $c^{\prime}\left(e_{i}\right)=w_{i}$. The separating equilibrium must solve the following program: ${ }^{28}$

$$
\begin{gathered}
\underset{(\boldsymbol{p}, \boldsymbol{w})}{\operatorname{Max}} \pi\left(v-\left(\theta_{H}-e_{H}\right)\left(h-w_{H}\right)-p_{H}\right)+(1-\pi)\left(v-\left(\theta_{L}-e_{L}\right)\left(h-w_{L}\right)-p_{L}\right) \\
\text { subject to } \\
c^{\prime}\left(e_{i}\right)=w_{i} \\
p_{i}-\left(\theta_{i}-e_{i}\right) w_{i}-c\left(e_{i}\right) \geq 0 \\
v-\left(\theta_{i}-e\left(w_{i}\right)\right)\left(h-w_{i}\right)-p_{i} \geq v-\left(\theta_{i}-e\left(w_{j}\right)\right)\left(h-w_{j}\right)-p_{j}
\end{gathered}
$$

The second set of constraints are the non-negative profit conditions for the firms. The third set are the incentive compatibility conditions for the two types of consumers: each consumer type should (at least weakly) prefer to choose the contract intended for his or her type. $^{29}$

\footnotetext{
${ }^{28}$ Implicit in this setup is the condition that the perfectly competitive equilibrium will maximize the consumer surplus subject to firms at least breaking even. See Rothschild and Stiglitz (1976) and Besanko and Thakor (1987). The program is also equivalent to consumers making a take-it-or-leave-it offer (and signaling their types) to firms.

${ }^{29}$ The solution also has to make sure that the consumers would be willing to choose respective $\left(p_{i}, w_{i}\right)$, rather than not buy, but this is easily satisfied when firms make zero profit in equilibrium.
} 
Proposition 2 Suppose it is socially efficient to serve both types of consumer with the optimal level of precaution (case 1). In a competitive Nash equilibrium, if it exists, firms offer a full warranty to the high-risk consumers, $w_{H}=h$, but a less-than-full warranty to the low-risk consumers, $w_{L}<h$. Firms break even by setting prices equal to the expected cost of serving each type, $p_{H}=\left(\theta_{H}-e^{*}\right) h+c\left(e^{*}\right)$ and $p_{L}=\left(\theta_{L}-e\left(w_{L}\right)\right) w_{L}+c\left(e\left(w_{L}\right)\right)$.

Proof. In a separating equilibrium, firms should make zero profits with respect to both types of consumer: $p_{i}-\left(\theta_{i}-e\left(w_{i}\right)\right) w_{i}-c\left(e\left(w_{i}\right)\right)=0 \forall i$. Suppose not. Given free entry, when there is a positive profit margin with respect to any type of consumer, firms that are serving that type of consumer will be infinitesimally small. First, suppose $p_{i}-\left(\theta_{i}-e\left(w_{i}\right)\right) w_{i}-c\left(e\left(w_{i}\right)\right)>0 \forall i$. Let $\varepsilon \equiv \min \left\{p_{H}-\left(\theta_{H}-e\left(w_{H}\right)\right) w_{H}-c\left(e\left(w_{H}\right)\right), p_{L}-\right.$ $\left.\left(\theta_{L}-e\left(w_{L}\right)\right) w_{L}-c\left(e\left(w_{L}\right)\right)\right\}$. Suppose a firm were to offer $\left(p_{H}-\varepsilon / 2, w_{H}\right)$ and $\left(p_{L}-\varepsilon / 2, w_{L}\right)$. Then the firm will be able to attract both types of consumer while satisfying the incentive compatibility conditions and realize a strictly positive profit.

Second, suppose $p_{H}-\left(\theta_{H}-e\left(w_{H}\right)\right) w_{H}-c\left(e\left(w_{H}\right)\right)>0$ but $p_{L}-\left(\theta_{L}-e\left(w_{L}\right)\right) w_{L}-$ $c\left(e\left(w_{L}\right)\right)=0$. Let $\varepsilon \equiv p_{H}-\left(\theta_{H}-e\left(w_{H}\right)\right) w_{H}-c\left(e\left(w_{H}\right)\right)$. If a firm were to offer $\left(p_{H}-\varepsilon / 2, w_{H}\right)$, it will attract all the high-type consumers and make a strictly positive profit. It may also attract low-type consumers, but, if that were so, the firm's profit margin will be even larger since $\left(\theta_{H}-e(w)\right) w+c(e(w))>\left(\theta_{L}-e(w)\right) w-c(e(w)) \forall w>0$.

Finally, suppose $p_{H}-\left(\theta_{H}-e\left(w_{H}\right)\right) w_{H}-c\left(e\left(w_{H}\right)\right)=0$ but $p_{L}-\left(\theta_{L}-e\left(w_{L}\right)\right) w_{L}-$ $c\left(e\left(w_{L}\right)\right)>0$. Choose $(\varepsilon, \delta)>0$ such that $v-\left(\theta_{H}-e\left(w_{L}\right)\right)\left(h-w_{L}\right)-p_{L}=v-\left(\theta_{H}-\right.$ $\left.e\left(w_{L}-\varepsilon\right)\right)\left(h-\left(w_{L}-\varepsilon\right)\right)-\left(p_{L}-\delta\right)$ and $p_{L}-\delta-\left(\theta_{L}-e\left(w_{L}-\varepsilon\right)\right)\left(w_{L}-\varepsilon\right)-c\left(e\left(w_{L}-\varepsilon\right)\right)>0$. That is, lower $w_{L}$ by $\varepsilon$ and $p_{L}$ by $\delta$ such that the high-type consumers are indifferent between $\left(p_{L}, w_{L}\right)$ and $\left(p_{L}-\varepsilon, w_{L}-\delta\right)$, while marginally reducing the profit margin. The assumption that $p_{L}-\left(\theta_{L}-e\left(w_{L}\right)\right) w_{L}-c\left(e\left(w_{L}\right)\right)>0$ implies that such a $(\varepsilon, \delta)$ exists. If a firm were to offer $\left(p_{L}-\varepsilon, w_{L}-\delta\right)$, the firm will attract all the low-type consumers (and no high-type consumers) and make a strictly positive profit. The condition, $\frac{\partial}{\partial w}\left(v-\left(\theta_{H}-e(w)\right)(h-\right.$ $w))>\frac{\partial}{\partial w}\left(v-\left(\theta_{L}-e(w)\right)(h-w)\right)$, ensures that the low-type consumers will strictly prefer $\left(p_{L}-\varepsilon, w_{L}-\delta\right)$ to $\left(p_{L}, w_{L}\right)$, while the high-type consumers will (weakly) prefer $\left(p_{H}, w_{H}\right)$ to $\left(p_{L}-\varepsilon, w_{L}-\delta\right)$.

It is also straightforward to verify that the incentive-compatibility condition for the high-type should bind but that for the low-type should be satisfied with slack: $v-\left(\theta_{H}-\right.$ $\left.e\left(w_{H}\right)\right)\left(h-w_{H}\right)-p_{H}=v-\left(\theta_{H}-e\left(w_{L}\right)\right)\left(h-w_{L}\right)-p_{L}$ but $v-\left(\theta_{L}-e\left(w_{L}\right)\right)\left(h-w_{L}\right)-p_{L}>$ $v-\left(\theta_{L}-e\left(w_{H}\right)\right)\left(h-w_{H}\right)-p_{H}$. First, note that the conditions $p_{L}-\left(\theta_{L}-e\left(w_{L}\right)\right) w_{L}-$ $c\left(e\left(w_{L}\right)\right)=0$ and $v-\left(\theta_{H}-e\left(w_{H}\right)\right)\left(h-w_{H}\right)-p_{H} \geq v-\left(\theta_{H}-e\left(w_{L}\right)\right)\left(h-w_{L}\right)-p_{L}$ imply that $w_{L}<w_{H}$. Now, suppose the high-type's incentive compatibility condition is satisfied with slack: $v-\left(\theta_{H}-e\left(w_{H}\right)\right)\left(h-w_{H}\right)-p_{H}>v-\left(\theta_{H}-e\left(w_{L}\right)\right)\left(h-w_{L}\right)-p_{L}$. Consider increasing $w_{L}$ by $\varepsilon$ and $p_{L}$ by $\delta$ so that $v-\left(\theta_{L}-e\left(w_{L}\right)\right)\left(h-w_{L}\right)-p_{L}=v-\left(\theta_{L}-e\left(w_{L}+\right.\right.$ $\varepsilon))\left(h-w_{L}-\varepsilon\right)-p_{L}-\delta$. Since $\frac{\partial}{\partial w}\left(v-\left(\theta_{L}-e(w)\right)(h-w)\right)>\frac{\partial}{\partial w}\left(\left(\theta_{L}-e(w)\right) w+c(e(w))\right)$ 
whenever $w<h,\left(p_{L}+\delta\right)-\left(\theta_{L}-e\left(w_{L}+\varepsilon\right)\right)\left(w_{L}+\varepsilon\right)-c\left(e\left(w_{L}+\varepsilon\right)\right) \equiv \zeta>0$. By offering $\left(p_{L}+\delta-\zeta / 2, w_{L}+\varepsilon\right)$, therefore, the firm will attract all low-type consumers and make a strictly positive profit. Hence, the incentive compatibility condition for the high-type consumers must bind in equilibrium.

With respect to the low-type's incentive compatibility constraint, the fact that $w_{L}<w_{H}$ and the assumption that $\frac{\partial}{\partial w}\left(v-\left(\theta_{H}-e(w)\right)(h-w)\right)>\frac{\partial}{\partial w}\left(v-\left(\theta_{L}-e(w)\right)(h-w)\right) \forall w<h$ imply that $v-\left(\theta_{L}-e\left(w_{L}\right)\right)\left(h-w_{L}\right)-\left\{v-\left(\theta_{H}-e\left(w_{L}\right)\right)\left(h-w_{L}\right)\right\}>v-\left(\theta_{L}-e\left(w_{H}\right)\right)(h-$ $\left.w_{H}\right)-\left\{v-\left(\theta_{H}-e\left(w_{H}\right)\right)\left(h-w_{H}\right)\right\}$. That is, the utility gap between the high and the lowtype consumers is larger with $w_{L}$ than with $w_{H}$. From the binding incentive compatibility condition for the high-type, if we add $v-\left(\theta_{H}-e\left(w_{L}\right)\right)\left(h-w_{L}\right)-p_{L}$ to the left hand side of the inequality and $v-\left(\theta_{H}-e\left(w_{H}\right)\right)\left(h-w_{H}\right)-p_{H}$ to the right hand side, and simplify, we get $v-\left(\theta_{L}-e\left(w_{L}\right)\right)\left(h-w_{L}\right)-p_{L}>v-\left(\theta_{L}-e\left(w_{H}\right)\right)\left(h-w_{H}\right)-p_{H}$.

When the zero-profit conditions are used to simplify the objective function and the binding incentive-compatibility condition is simplified, the problem becomes

$$
\begin{gathered}
\underset{\boldsymbol{w}}{\operatorname{Max}} \pi\left(v-\left(\theta_{H}-e\left(w_{H}\right)\right) h-c\left(e\left(w_{H}\right)\right)\right)+(1-\pi)\left(v-\left(\theta_{L}-e\left(w_{L}\right)\right) h-c\left(e\left(w_{L}\right)\right)\right. \\
\quad \text { subject to } \\
\left(e\left(w_{L}\right)-e\left(w_{H}\right)\right) h+\left(\theta_{H}-\theta_{L}\right) w_{L}+c\left(e\left(w_{H}\right)\right)-c\left(e\left(w_{L}\right)\right)=0 .
\end{gathered}
$$

The Lagrangian is

$$
\begin{array}{r}
\mathcal{L}(\boldsymbol{w}, \lambda)=\pi\left(v-\left(\theta_{H}-e\left(w_{H}\right)\right) h-c\left(e\left(w_{H}\right)\right)\right)+(1-\pi)\left(v-\left(\theta_{L}-e\left(w_{L}\right)\right) h-c\left(e\left(w_{L}\right)\right)\right. \\
-\lambda\left\{\left(e\left(w_{L}\right)-e\left(w_{H}\right)\right) h+\left(\theta_{H}-\theta_{L}\right) w_{L}+c\left(e\left(w_{H}\right)\right)-c\left(e\left(w_{L}\right)\right)\right\} .
\end{array}
$$

The first-order conditions are

$$
\begin{gathered}
e^{\prime}\left(w_{H}\right)(\pi+\lambda)\left(h-w_{H}\right)=0 \\
e^{\prime}\left(w_{L}\right)\left\{(1-\pi)\left(h-w_{L}\right)-\lambda\left(h-w_{L}+\left(\theta_{H}-\theta_{L}\right) / e^{\prime}\left(w_{L}\right)\right)\right\}=0 \\
\left(e\left(w_{L}\right)-e\left(w_{H}\right)\right) h+\left(\theta_{H}-\theta_{L}\right) w_{L}+c\left(e\left(w_{H}\right)\right)-c\left(e\left(w_{L}\right)\right)=0
\end{gathered}
$$

Since the Lagrange multiplier $\lambda>0$ in equilibrium, the first equality can be satisfied only by setting $w_{H}=h$. From the second equation (or the third equation), if we were to set $w_{L}=h$, the left hand side will be strictly negative (or strictly positive), violating optimality. To satisfy the equality, we need $w_{L}<h$. The corresponding prices are given by the firms' binding zero-profit constraints: $p_{H}=\left(\theta_{H}-e(h)\right) h+c(e(h))$ and $p_{L}=$ $\left(\theta_{L}-e\left(w_{L}\right)\right) w_{L}+c\left(e\left(w_{L}\right)\right)$.

Figure 1 graphically illustrates the proposed equilibrium for Case 1. The two steeper curves depict the high-risk and low-risk consumers' gross utilities as a function of the warranty $w$. (For ease of illustration, the curves have been drawn as straight lines. ${ }^{30}$ ) Note

\footnotetext{
${ }^{30}$ The slope of consumer type $i$ 's valuation is $\left(\theta_{i}-e(w)\right)+e^{\prime}(w)(h-w)$ and the slope of the cost of serving type $i$ is $\left(\theta_{i}-e(w)\right)$. Since $e^{\prime}(w)>0,(1)$ the slope is decreasing for all the curves and (2) the slope of the consumer valuation curve is always higher than that of the corresponding cost curve (except when $h=w$ ).
} 
that the gross utilities are increasing in the warranty coverage and that the low-risk consumer has a higher gross utility than the high-risk consumer (except when $w=h$ ). The two flatter lines depict the firms' costs of serving the two different consumer types. Note that the cost of serving a high-risk consumers is higher than the cost of serving a low-risk consumers (except when $w=0$ ). For the high-risk consumers, the full warranty with $p_{H}=\left(\theta_{H}-e(h) h\right)+c(e(h))$ is offered in equilibrium, and these consumers realize a positive surplus, graphically represented as $\beta$. The warranty for the low-risk consumers $\left(w_{L}\right)$ is chosen so that the high-risk consumers are just indifferent between choosing $w_{H}=h$ and $w_{L}$ (or weakly prefers choosing $\left.w_{H}\right)$. With $p_{L}=\left(\theta_{L}-e\left(w_{L}\right) w_{L}\right)+c\left(e\left(w_{L}\right)\right)$ and $w_{L}$, the low-risk consumers earn a surplus, graphically represented as $\gamma$.

If the competitive market were to offer contract(s) with full warranty $(w=h)$ to both types of consumer, given (1) free entry and (2) that all consumers will strictly prefer a contract with lower price, the market must charge a price equal to the average cost of serving both types $\left(p=\left(\bar{\theta}-e^{*}\right) h+c\left(e^{*}\right)\right)$. If that were the case, however, firms would have an incentive to offer a contract with less-than-full insurance just to lure the low-risk consumers and make a strictly positive profit (as described in the proof of Lemma 1). In a separating equilibrium, therefore, the less-than-full insurance for the low-risk consumers $\left(p_{L}, w_{L}\right)$ must be just so that the high-risk consumers would be indifferent between the two contracts offered in the market (or slightly prefer the one intended for them). From the diagram, this warranty is given by the point where the difference between the high-risk consumer's utility and the cost of providing $w_{L}$ to them is equal to $\beta$. If a firm were offer any warranty below this, that contract will be strictly dominated. Conversely, if any firm were to offer any warranty higher than this, that firm will attract both types of consumer, resulting in a negative profit. ${ }^{31}$

Although the last proposition characterizes a competitive Nash equilibrium, it does not ensure its existence. Due to the adverse selection problem, existence is not guaranteed. In the proposed separating equilibrium, each type of consumer realizes a certain amount of consumer surplus. If the average cost of serving both types is sufficiently low, however, a firm can offer a single contract that attracts both types of consumer and make a strictly positive profit. At the same time, we know from the previous lemma that such a pooling outcome cannot be an equilibrium, either. To ensure existence, we need to make sure that the average cost of serving both types of consumer is not too low. The following corollary presents the conditions under which the proposed competitive separating equilibrium exists.

Corollary 1 If $(\bar{\theta}-e(h)) h+c(e(h)) \geq v-\gamma$ where $\gamma \equiv v-\left(\theta_{L}-e\left(w_{L}\right)\right)\left(h-w_{L}\right)-\left\{\left(\theta_{L}-\right.\right.$ $\left.\left.e\left(w_{L}\right)\right) w_{L}+c\left(e\left(w_{L}\right)\right)\right\}$, there is no profitable deviation, and the separating Nash equilibrium exists.

\footnotetext{
${ }^{31}$ This statement is subject to the caveat that the average cost of serving both types is not too low, which is discussed in detail in the following paragraph.
} 


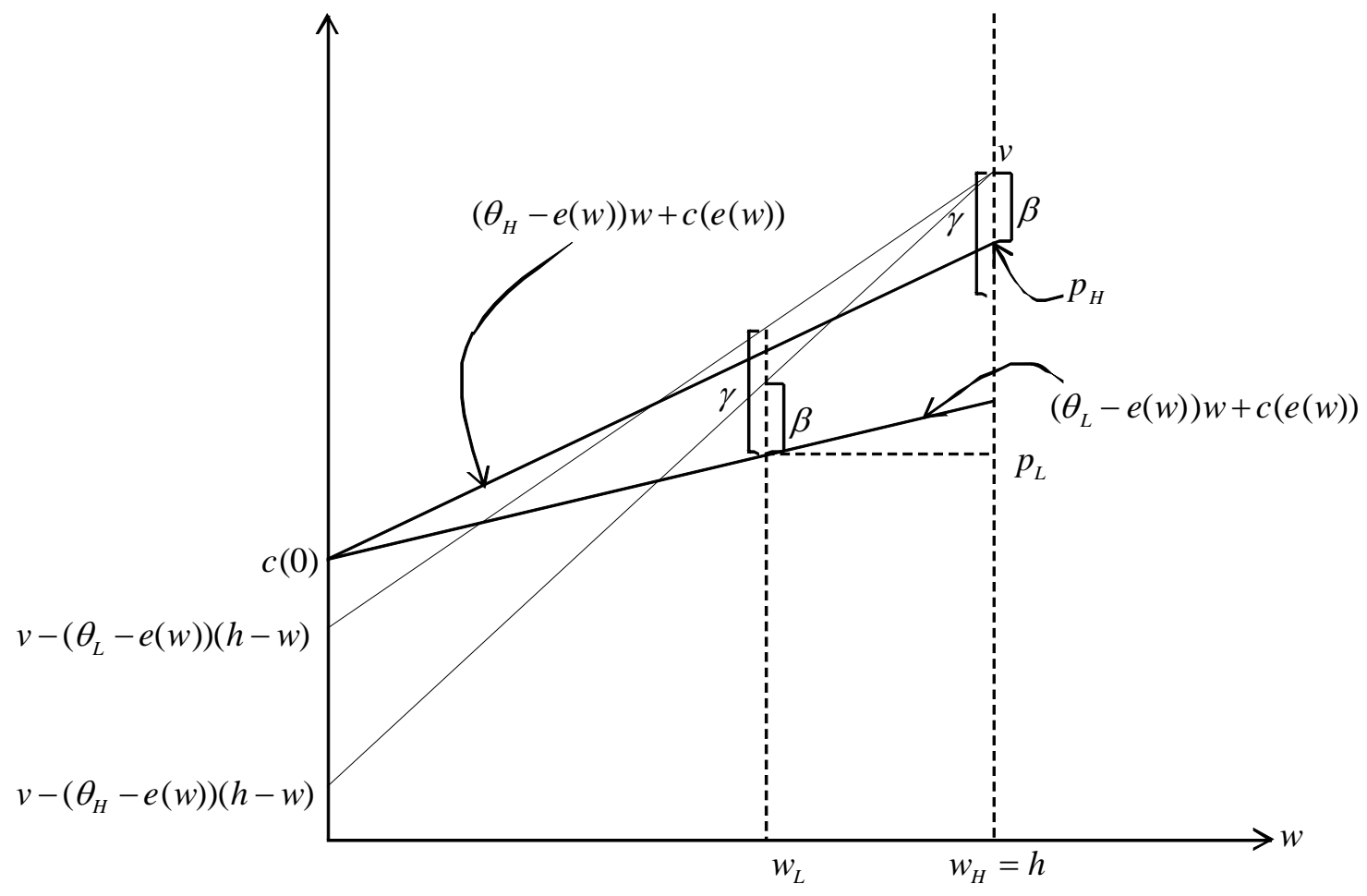

Figure 1: when $v \geq\left(\theta_{H}-e^{*}\right) h+c\left(e^{*}\right)>\left(\theta_{L}-e^{*}\right) h+c\left(e^{*}\right)$ 
Proof. Since $\frac{\partial}{\partial w}\left(v-\left(\theta_{i}-e(w)\right) h-c(e(w))\right)>0$, if a firm were to deviate by offering a pooling contract, the maximal deviation can be achieved by offering full warranty. Hence, to prevent deviation, we need to ensure that offering full warranty is not profitable. $\gamma$ stands for the surplus the low-risk consumers realize in the separating equilibrium. If $(\bar{\theta}-$ $e(h)) h+c(e(h))<v-\gamma$, by offering $w=h$ and $p$ such that $v-\gamma>p>(\bar{\theta}-e(h)) h+c(e(h))$, the deviating firm can attract both types of consumer and make a strictly positive profit. Hence, $(\bar{\theta}-e(h)) h+c(e(h)) \geq v-\gamma$ is a sufficient condition for the existence of the proposed separating Nash equilibrium.

To understand this corollary more intuitively, let us go back to Figure 1. In the proposed separating equilibrium, the low-risk consumers' surplus is given by $\gamma$, the difference between their gross utility from having a contractual warranty $w_{L}$ and the market price in this contract, $p_{L}$. In order to prevent any firm from deviating from this equilibrium, we need to make sure that the most profitable (maximal) deviation is prevented, which happens when a firm were to offer full warranty $(w=h)$. Could a firm offer full warranty, attract both types of consumer, and make a strictly positive profit? That depends on the average cost of providing full warranty and serving both types. If the average cost were to fall below $v-\gamma$, then by offering $w=h$ with price anywhere between $v-\gamma$ and the average cost $((\bar{\theta}-e(h)) h+c(e(h)))$, the firm will make a strictly positive profit and attract both types of consumer. With full insurance, both types of consumer are willing to pay up to $v$. Since the price is below $v-\gamma$, both types of consumer will strictly prefer this pooling contract to the proposed separating contracts. Hence, when the average cost is sufficiently low, even the separating equilibrium will not exist. And, from Lemma 1, we also know that the pooling equilibrium cannot exist, either.

In sum, when it is socially efficient to serve both types of consumer with the socially optimal level of precaution (case 1), then there are two possible outcomes. First, when the average cost of serving both types of consumer is above a threshold $((\bar{\theta}-e(h)) h+c(e(h))>$ $v-\gamma)$, then a competitive separating equilibrium exists. In this separating equilibrium, firms offer low-risk consumers a less-than-full warranty in order to induce self-selection by the low-risk types. The less-than-full warranty, in turn, translates to suboptimal level of precaution $\left(e<e^{*}\right)$. Second, when the average cost of serving both types of consumer is below the threshold $((\bar{\theta}-e(h)) h+c(e(h))<v-\gamma)$, it is possible that there is a complete break-down of the market, in the sense that no competitive Nash equilibrium exists. ${ }^{32}$ This is true even though consumers all place a higher value on the product than the cost of production with full warranty.

\subsection{Case 2: Only Low-Risk Consumers Should Purchase the Product}

Suppose $\left(\theta_{H}-e^{*}\right) h+c\left(e^{*}\right)>v \geq\left(\theta_{L}-e^{*}\right) h+c\left(e^{*}\right)$. Unlike the previous case, now it is no longer efficient to serve the high-risk consumers. The assumption $\left(\theta_{H}-e^{*}\right) h+c\left(e^{*}\right)>v$

\footnotetext{
${ }^{32}$ If we were to impose a stronger equilibrium concept, the existence problem could be solved. The equilibrium will still be inefficient, however. See Wilson (1977).
} 
implies that the social surplus from serving the high-risk consumers is negative regardless of the size of the warranty. The first best is to serve only the low-risk consumers with a full warranty $(w=h)$ and for the firms to choose the efficient level of precaution $\left(e=e^{*}\right)$ for them. The first best cannot be achieved in a competitive equilibrium, however, because, with a full warranty, both types of consumer have a willingness-to-pay that is equal to $v$, and when firms price the product at less than $v$, they cannot prevent the high-risk consumers from also purchasing the product. In order to prevent the high-risk consumers from also participating in the market, the equilibrium warranty for the low-risk consumers has to be less than full. ${ }^{33}$

Suppose there is a competitive, separating equilibrium where all firms offer $\left(p_{0}, w_{0}\right)$, only the low-risk consumers purchase, and firms choose the level of precaution given by $c^{\prime}\left(e_{0}\right)=w_{0}$. The equilibrium must solve the following problem:

$$
\begin{gathered}
\underset{\left(p_{0}, w_{0}\right)}{\operatorname{Max}} v-\left(\theta_{L}-e_{0}\right)\left(h-w_{0}\right)-p_{0} \\
\text { subject to } \\
c^{\prime}\left(e_{0}\right)=w_{0} \\
p_{0}-\left(\theta_{L}-e_{0}\right) w_{0}-c\left(e_{0}\right) \geq 0 \\
v-\left(\theta_{H}-e_{0}\right)\left(h-w_{0}\right)-p_{0} \leq 0
\end{gathered}
$$

The second constraint is the non-negative profit condition and the third represents the incentive compatibility condition for the high-risk consumers, saying that the high-risk consumers do not find it in their interest to purchase the product. ${ }^{34}$

Proposition 3 Suppose it is socially efficient to serve only the low-risk consumers with the optimal level of precaution (case 2). In a competitive Nash equilibrium, if it exists, all firms offer a contract with a less-than-full warranty, $w_{0}<h$, only the low-risk consumers purchase, and firms break even, $p_{0}=\left(\theta_{L}-e\left(w_{0}\right)\right) w_{0}+c\left(e\left(w_{0}\right)\right)$.

Proof. Based on Lemma 1, we cannot have an equilibrium where all firms set $w=h$, since that would only induce a pooling equilibrium. Therefore, we must have $w_{0}<h$. In equilibrium, both constraints, $p_{0}-\left(\theta_{L}-e_{0}\right) w_{0}-c\left(e_{0}\right) \geq 0$ and $v-\left(\theta_{H}-e\left(w_{0}\right)\right)(h-$ $\left.w_{0}\right)-p_{0} \leq 0$ must bind. Suppose not. First, suppose $p_{0}-\left(\theta_{L}-e_{0}\right) w_{0}-c\left(e_{0}\right)>0$ and $v-\left(\theta_{H}-e\left(w_{0}\right)\right)\left(h-w_{0}\right)-p_{0}=0$. Because the profit margin is strictly positive, with free entry, each firm will be infinitesimally small. Since $\left(\theta_{H}-e(w)\right)+e^{\prime}(w)(h-w)>\left(\theta_{L}-e(w)\right)$ whenever $w<h, \exists(\varepsilon, \delta)>0$ such that $p_{0}-\left(\theta_{L}-e\left(w_{0}-\varepsilon\right)\right)\left(w_{0}-\varepsilon\right)-c\left(e\left(w_{0}-\varepsilon\right)\right) \geq 0$

\footnotetext{
${ }^{33}$ If the price were equal to $v$, consumers would all be indifferent between purchasing and not purchasing, and firms would get all of the rents. Per Lemma 1, this cannot be an equilibrium, either.

${ }^{34}$ The solution also has to make sure that the low-risk consumers would be willing to purchase $\left(p_{0}, w_{0}\right)$ but this is easily satisfied when firms make zero profit in equilibrium.
} 
and $v-\left(\theta_{H}-e\left(w_{0}-\varepsilon\right)\right)\left(h-\left(w_{0}-\varepsilon\right)\right)-\left(p_{0}-\delta\right)=0$. If a firm were to deviate and offer $\left(w_{0}-\varepsilon, p_{0}-\delta / 2\right)$, the firm will attract all the low-type consumers and make a strictly positive profit.

Second, suppose $p_{0}-\left(\theta_{L}-e_{0}\right) w_{0}-c\left(e_{0}\right)=0$ and $v-\left(\theta_{H}-e\left(w_{0}\right)\right)\left(h-w_{0}\right)-p_{0}<0$. Again, since $\left(\theta_{H}-e(w)\right)+e^{\prime}(w)(h-w)>\left(\theta_{L}-e(w)\right)$ whenever $w<h, \exists(\varepsilon, \delta)>0$ such that $p_{0}-\left(\theta_{L}-e\left(w_{0}+\varepsilon\right)\right)\left(w_{0}+\varepsilon\right)-c\left(e\left(w_{0}+\varepsilon\right)\right)=0$ and $v-\left(\theta_{H}-e\left(w_{0}+\varepsilon\right)\right)\left(h-\left(w_{0}+\right.\right.$ $\varepsilon))-\left(p_{0}+\delta\right) \leq 0$. At $\left(w_{0}+\varepsilon, p_{0}+\delta\right)$, the low-type consumers are enjoying a surplus of $v-\left(\theta_{L}-e\left(w_{0}+\varepsilon\right)\right)\left(h-\left(w_{0}+\varepsilon\right)\right)-\left(p_{0}+\delta\right)>v-\left(\theta_{L}-e\left(w_{0}\right)\right)\left(h-w_{0}\right)-p_{0}$. Let the difference be $\zeta$. If a firm were to offer $\left(w_{0}+\varepsilon, p_{0}+\delta+\zeta / 2\right)$, it will attract all the low-type consumers and make a strictly positive profit. If both constraints are satisfied with slack, a profitable deviation can be constructed using either of the approaches. If both were satisfied with slack, a firm can profitably deviate through a combination of both maneuvers. In equilibrium, therefore, both constraints must bind.

The binding constraints produce the optimal solution $\left(p_{0}, w_{0}\right)$. Since $\left(\theta_{H}-e(w)\right) w+$ $c(e(w))>v-\left(\theta_{H}-e(w)\right)(h-w) \forall w, v>\left(\theta_{L}-e(h)\right) h+c(e(h))$, and $\left(\theta_{H}-e(w)\right) w+c(e(w))=$ $\left(\theta_{L}-e(w)\right) w+c(e(w))$ when $w=0$, it is clear that the solution that satisfies both $p_{0}-\left(\theta_{L}-e_{0}\right) w_{0}-c\left(e_{0}\right)=0$ and $v-\left(\theta_{H}-e\left(w_{0}\right)\right)\left(h-w_{0}\right)-p_{0}=0$ exists and also that $w_{0}<h$.

Figure 2 graphically presents the proposed equilibrium. Unlike the previous case, now the cost of insuring the high-risk consumers lies everywhere above their willingness-to-pay. If the competitive market were to offer a full warranty (which will be along the vertical dotted line at $h$ ), both types of consumer have a willingness-to-pay that is equal to $v$, making it impossible to distinguish them as the social optimality requires. In a separating equilibrium where (1) only the low-risk consumers are served and (2) firms break even, the warranty has to be set at a level where the high-risk consumers are just indifferent between purchasing and not purchasing. This contract is given by the point where the high-risk consumers' utility crosses the cost of providing warranty to the low-risk consumers. At $\left(p_{0}, w_{0}\right)$, the high-risk consumers, even if they were to buy, would realize a utility of zero. The low-risk consumers, on the other hand, are realizing a surplus equal to $\alpha$.

While the proposed equilibrium is intuitively attractive, similar to the previous case, its existence (or stability) is not guaranteed. Even though it is inefficient to serve the high-risk consumers, if the average cost of serving both types of consumer is sufficiently low, a firm may profitably deviate by offering a pooling contract that serves both types. Combining this low average cost condition with Lemma 1, in turn, implies that there would be no competitive Nash equilibrium. On the other hand, the existence is, compared to the previous case, a bit easier since, by assumption, the cost of serving the high-risk consumers is 


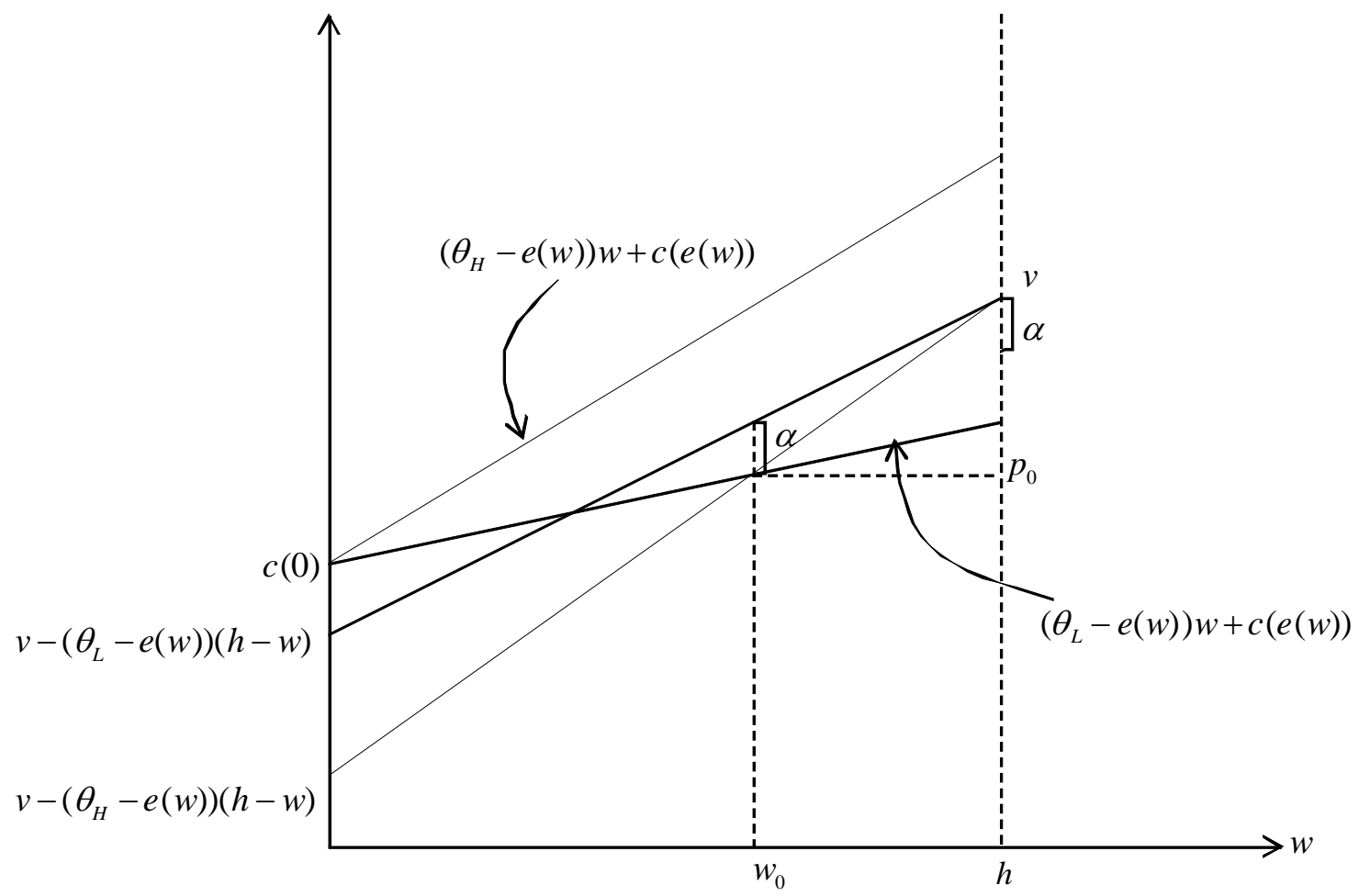

Figure 2: when $\left(\theta_{H}-e^{*}\right) h+c\left(e^{*}\right)>v \geq\left(\theta_{L}-e^{*}\right) h+c\left(e^{*}\right)$ 
inefficiently high. The following corollary establishes the conditions under which profitable deviation using a pooling contract is not feasible.

Corollary 2 If $\left(\bar{\theta}-e^{*}\right) h+c\left(e^{*}\right) \geq v-\alpha$ where $\alpha \equiv v-\left(\theta_{L}-e\left(w_{0}\right)\right)\left(h-w_{0}\right)-\left\{\left(\theta_{L}-\right.\right.$ $\left.\left.e\left(w_{0}\right)\right) w_{0}+c\left(e\left(w_{0}\right)\right)\right\}$, there is no profitable deviation and the separating Nash equilibrium exists.

Proof. The proof is similar to that in case 1. Since $\frac{\partial}{\partial w}\left(v-\left(\theta_{i}-e(w)\right) h-c(e(w))\right)>0$, if a firm were to deviate by offering a pooling contract, the maximal deviation can be achieved by offering full warranty. Hence, to prevent deviation, we need to ensure that offering full warranty is not profitable. $\alpha$ stands for the surplus the low-risk consumers realize in the separating equilibrium. If $\left(\bar{\theta}-e^{*}\right) h+c\left(e^{*}\right)<v-\alpha$, by offering $w=h$ and $p$ such that $v-\alpha>p>\left(\bar{\theta}-e^{*}\right) h+c\left(e^{*}\right)$, the deviating firm can attract both types of consumer and make a strictly positive profit. Hence, $\left(\bar{\theta}-e^{*}\right) h+c\left(e^{*}\right) \geq v-\alpha$ is a sufficient condition for the existence of the proposed separating Nash equilibrium.

The corollary can be more intuitively explained through Figure 2. In the proposed separating equilibrium $\left(p_{0}, w_{0}\right)$, the low-risk consumers earn a surplus of $\alpha$. If a firm were to maximally deviate from this equilibrium and offer a full warranty, it will attract both types of consumer. If the average cost of serving both types of consumer with full warranty $\left(\left(\bar{\theta}-e^{*}\right) h+c\left(e^{*}\right)\right)$, falls anywhere below $v-\alpha$ (lies below $v-\alpha$ on the vertical dotted line through $h$ ), firms will have a profitable deviation. By charging a price, say $\widehat{p}$, that is between the average cost $\left(\left(\bar{\theta}-e^{*}\right) h+c\left(e^{*}\right)\right)$ and $v-\alpha$, it will attract both types of consumer and make a strictly positive profit. The high-risk consumers will enjoy a strictly positive utility of $v-\widehat{p}$. The low-risk consumers will also strictly prefer this contract $(\widehat{p}, h)$ since their surplus will be larger than $\alpha$. To prevent this deviation, the average cost of providing full warranty has to lie above $v-\alpha$. With that, if any firm were to deviate and offer full warranty, it will only attract high-risk consumers and realize a loss.

\section{$5 \quad$ Public Policy Implications}

This section characterizes the optimal public policy response to the adverse selection problem identified in the previous section. We will assume that the social planner can dictate the warranty terms of the sales contracts, $w$, but cannot directly control the market price, $p$. In contrast to the benchmark case where the social planner controlled the price in addition to the warranty, the first-best outcome cannot always be achieved here. We will see, however, that the warranty is a valuable instrument for raising the levels of product safety in the market. 


\subsection{Case 1: Both Types of Consumer Should Purchase the Product}

Suppose $v \geq\left(\theta_{H}-e^{*}\right) h+c\left(e^{*}\right)>\left(\theta_{L}-e^{*}\right) h+c\left(e^{*}\right)$, so that it is socially efficient for both types of consumer to be served by the market with full warranty and precaution level $e^{*}$. Recall that perfect competition led to either (1) low-risk consumers purchasing products with less-than-full warranties and suboptimal safety attributes (and high-risk consumers purchasing optimally safe products) or (2) a complete break-down of the market. In either case, the socially optimal policy is relatively straightforward to derive.

Proposition 4 Suppose it is socially efficient to serve both types of consumer with the optimal level of precaution (case 1). The optimal social policy is to require all firms to offer a full warranty, $w=h$. Firms subsequently choose optimal precautions, $e=e^{*}$, charge a price that allows them to break even on average, $p=\left(\bar{\theta}-e^{*}\right) h+c\left(e^{*}\right)$, and sell to both types of consumer. ${ }^{35}$

By mandating a full warranty or, equivalently, by allowing consumers to recover for the harm suffered notwithstanding any prior contractual limitation, the social planner can implement the first-best outcome. The crux of the problem with the unregulated market was that the firms had an incentive to cream-skim only the low-risk consumers with a contract specifying a less-than-full warranty. Mandating a full warranty solves the problem because it prevents firms from inefficiently undercutting each other. Since the willingnessto-pay for full insurance for both types of consumer is higher than the average cost of providing full insurance, with a mandatory full warranty and perfect competition, firms will charge the price that is equal to the average cost of serving both types, both types of consumer will purchase, and firms will choose the optimal level of precaution. Both the social welfare and the consumer surplus are maximized. ${ }^{36}$

\subsection{Case 2: Only Low-Risk Consumers Should Purchase the Product}

Now suppose $\left(\theta_{H}-e^{*}\right) h+c\left(e^{*}\right)>v \geq\left(\theta_{L}-e^{*}\right) h+c\left(e^{*}\right)$, so that only the low-risk consumers should purchase the product. Constructing the optimal social policy is more challenging in this case. Simply requiring all firms to offer full warranty $(w=h)$, as in case 1 , may not work. Because both types of consumers are willing to pay up to $v$ for the product with full warranty, mandating full warranty will lead to either (1) a destruction of the market in which no consumers are served when the average cost of serving both types lies above $v$, or

\footnotetext{
${ }^{35}$ The proof is immediate. Note that since $v>p=\left(\bar{\theta}-e^{*}\right) h+c\left(e^{*}\right)$, when liability is full, both types of consumers will purchase the product.

${ }^{36}$ If $(E(\theta)-e(h)) h+c(e(h)) \geq v-\gamma$, the low-risk consumers will be worse off compared to the separating equilibrium: their surplus is strictly less than $\gamma$. The fact that the low-risk consumers are subsidizing the high-risk ones creates an incentive for them to signal their type to the market (by taking on less-than-full warranty). Although the signaling is in their private interest, it creates a welfare loss. See Aghion and Hermalin (1990) for a similar story.
} 
(2) both types of consumer purchasing the product when the average cost falls below $v$. In the former case, inefficiency stems from the low-risk consumers being unable to purchase the product, whereas in the latter, from the high-risk consumers participating in the market.

Proposition 5 Suppose it is socially efficient to serve only the low-risk consumers with the optimal level of precaution (case 2). When $\left(\bar{\theta}-e^{*}\right) h+c\left(e^{*}\right) \geq v$, an equilibrium that is arbitrarily close to the first best can be implemented in dominant strategies through the policy of mandating $w(\Delta)=h-\Delta$ with $\Delta \rightarrow 0$. When $\left(\bar{\theta}-e^{*}\right) h+c\left(e^{*}\right)<v$, the optimal policy is to either mandate (1) a warranty that is implicitly determined by $(\bar{\theta}-e(w)) w+c(e(w))=v-\left(\theta_{H}-e(w)\right)(h-w)$ or (2) a full warranty $(w=h)$.

Proof. Suppose $\left(\bar{\theta}-e^{*}\right) h+c\left(e^{*}\right) \geq v$ and the policy mandates $w(\Delta)=h-\Delta$ with $\Delta \rightarrow 0$. Under that policy, firms will choose precautions $e(w(\Delta))$ and competition will drive the price down to $v-\left(\theta_{H}-e(w(\Delta))\right) \Delta$. Only the low-risk consumers will purchase at this price. Because $(\bar{\theta}-e(w(\Delta))) \Delta+c(e(w(\Delta)))>v-\left(\theta_{H}-e(w(\Delta))\right) \Delta$ whenever $\Delta>0$, no firm can profitably deviate by setting a price strictly below $v-\left(\theta_{H}-e(w(\Delta))\right) \Delta$. and attracting both types of consumer. If a firm were to do so, it would make a strictly negative profit. Although the equilibrium profit margin, $\left.p-\left\{\theta_{L}-e(w(\Delta))\right)(h-\Delta)+c(e(w(\Delta)))\right\}$, is strictly positive, since, by assumption, the cost of entry is zero, firms will be infinitesimally small.

When $\left(\bar{\theta}-e^{*}\right) h+c\left(e^{*}\right)<v$, we need to consider two sub-cases. First, if the policy were to mandate a warranty $\left(w^{\prime}\right)$ such that $w^{\prime} \rightarrow h$, because the average cost lies below the high-risk consumers' valuation, i.e., $\left(\bar{\theta}-e\left(w^{\prime}\right)\right) w^{\prime}+c\left(e\left(w^{\prime}\right)\right)<v-\left(\theta_{H}-e\left(w^{\prime}\right)\right)\left(h-w^{\prime}\right)$, all firms will set $p^{\prime}=\left(\bar{\theta}-e\left(w^{\prime}\right)\right) w^{\prime}+c\left(e\left(w^{\prime}\right)\right)$, make zero profit, and serve both types of consumer. The equilibrium social welfare is given by $v-\left(\bar{\theta}-e\left(w^{\prime}\right)\right) h-c\left(e\left(w^{\prime}\right)\right)$. Since the welfare is maximized by setting $w^{\prime}=h$, if the policy were to choose any warranty level so as to serve both types of consumer, it should mandate full warranty. Firms will break even (zero profit margin) by charging $p^{\prime}=\left(\bar{\theta}-e^{*}\right) h+c\left(e^{*}\right)$.

Second, the policy could mandate a warranty that is given by $(\bar{\theta}-e(w)) w+c(e(w))=$ $v-\left(\theta_{H}-e(w)\right)(h-w)$. Let that warranty be denoted $w^{\prime \prime}$. The equilibrium price is $p^{\prime \prime}=v-\left(\theta_{H}-e\left(w^{\prime \prime}\right)\right)\left(h-w^{\prime \prime}\right)$. Since $\left(\bar{\theta}-e^{*}\right) h+c\left(e^{*}\right)<v$ and $\left(\bar{\theta}-e\left(w_{0}\right)\right) w_{0}+c\left(e\left(w_{0}\right)\right)>v-$ $\left(\theta_{H}-e\left(w_{0}\right)\right)\left(h-w_{0}\right)$, we must have $w_{0}<w^{\prime \prime}<h$ and only the low-risk consumers purchasing, thereby improving welfare. While each firm's profit margin, $\left.p^{\prime \prime}-\left\{\theta_{L}-e\left(w^{\prime \prime}\right)\right) w^{\prime \prime}+c\left(e\left(w^{\prime \prime}\right)\right)\right\}$, will be strictly positive, firms will be infinitesimally small given free entry. No firm can profitably deviate because if it were to offer any price strictly below $p^{\prime \prime}$, it will attract both types of consumer and will make a strictly negative profit. Pricing above $p^{\prime \prime}$ is also (weakly) dominated.

The optimal policy depends on the relative size of the deadweight loss in both cases and their comparison to the competitive outcome $\left(p_{0}, w_{0}\right)$. In the unregulated competitive 
equilibrium $\left(p_{0}, w_{0}\right)$, assuming its existence, the inefficiency stemmed from incomplete warranty for the low-risk consumers: $(1-\pi)\left\{\left[e^{*} h-c\left(e^{*}\right)\right]-\left[e\left(w_{0}\right) h-c\left(e\left(w_{0}\right)\right)\right]\right\}>0$. Under the first policy option, the welfare loss comes from the high-risk consumers' purchase of the product: $\pi\left(\left(\theta_{H}-e^{*}\right) h+c\left(e^{*}\right)-v\right)>0$. As the fraction of high-risk consumers $(\pi)$ grows larger, the inefficiency under the first policy gets larger while that under the unregulated competitive equilibrium gets smaller. When the fraction of high-risk consumers is large (but not large enough to satisfy $\left(\bar{\theta}-e^{*}\right) h+c\left(e^{*}\right)>v$ ), mandating full warranty may be welfare reducing. In the second case, the welfare loss stems from incomplete warranty for the low-risk consumers: $(1-\pi)\left\{\left[e^{*} h-c\left(e^{*}\right)\right]-\left[e\left(w^{\prime \prime}\right) h-c\left(e\left(w^{\prime \prime}\right)\right)\right]\right\}>0$. Unlike the first policy option, the second policy strictly dominates the unregulated competitive equilibrium $\left(p_{0}, w_{0}\right)$ in terms of welfare, since $w^{\prime \prime}>w_{0}$ so long as $\pi<1$.

When the average cost of providing full warranty to both types is sufficiently high $\left(\left(\bar{\theta}-e^{*}\right) h+c\left(e^{*}\right) \geq v\right.$ and represented as the higher dotted diagonal line in Figure 3$)$, we can implement a market outcome that is arbitrarily close to the first best by requiring a warranty level that is slightly below the full level. The argument is similar to the one presented as the social welfare benchmark in section 3 . When the social planner mandates a warranty level that is below the full level (represented as $w^{\prime}$ in Figure 3), in equilibrium, firms will offer a price (represented as $p^{\prime}$ in Figure 3) that is equal to (or slightly higher than) the high-risk consumer's valuation $\left(v-\left(\theta_{H}-e\left(w^{\prime}\right)\right)\left(h-w^{\prime}\right)\right)$ and serve only the low-risk consumers. If a firm were to deviate and charge a lower price $\left(p<p^{\prime}\right)$, it will attract both types of consumer and incur a loss since, by assumption, the cost of serving both types lies above $p^{\prime}$. Charging a higher price $\left(p>p^{\prime}\right)$ is also strictly dominated because no one will choose that contract. Given that the equilibrium price $\left(p^{\prime}\right)$ lies between the low-risk consumers' willingness-to-pay and the firms' cost of serving them $\left(v-\left(\theta_{L}-e\left(w^{\prime}\right)\right)\left(h-w^{\prime}\right)>p^{\prime}>\left(\theta_{L}-e\left(w^{\prime}\right)\right) w^{\prime}+c\left(e\left(w^{\prime}\right)\right)\right)$, both the low-risk consumers and the firms will realize a positive surplus.

To maximize social welfare, the social planner should mandate a warranty that is as close to the full level as possible. As the mandated warranty approaches the full level $\left(w^{\prime} \rightarrow h\right)$, a couple of things will happen. First, the equilibrium price will approach the consumers' gross valuation with full warranty $\left(p^{\prime} \rightarrow v\right)$, and the low-risk consumers' surplus will disappear in the limit. From Figure 3, this can be seen by observing that as $w^{\prime}$ approaches $h, p^{\prime}$ will crawl along the line that represents the high-risk consumers' willingness-to-pay and approach $v$, thus eliminating the low-risk consumers' surplus. At the same time, the size of the deterrence inefficiency will get smaller $\left(e^{\prime} \rightarrow e^{*}\right)$ as the firms take more safety precautions with larger warranty. Finally, although all the surplus $\left(v-\left(\theta_{L}-e^{*}\right) h-c\left(e^{*}\right)\right)$ will be captured by the firms in the limit, with free entry, each firm will be infinitesimally small. In sum, when the average cost of serving both types of consumer is sufficiently high, by mandating a warranty that is slightly below the full level, the social planner can implement an equilibrium that is arbitrarily close to the first best. 


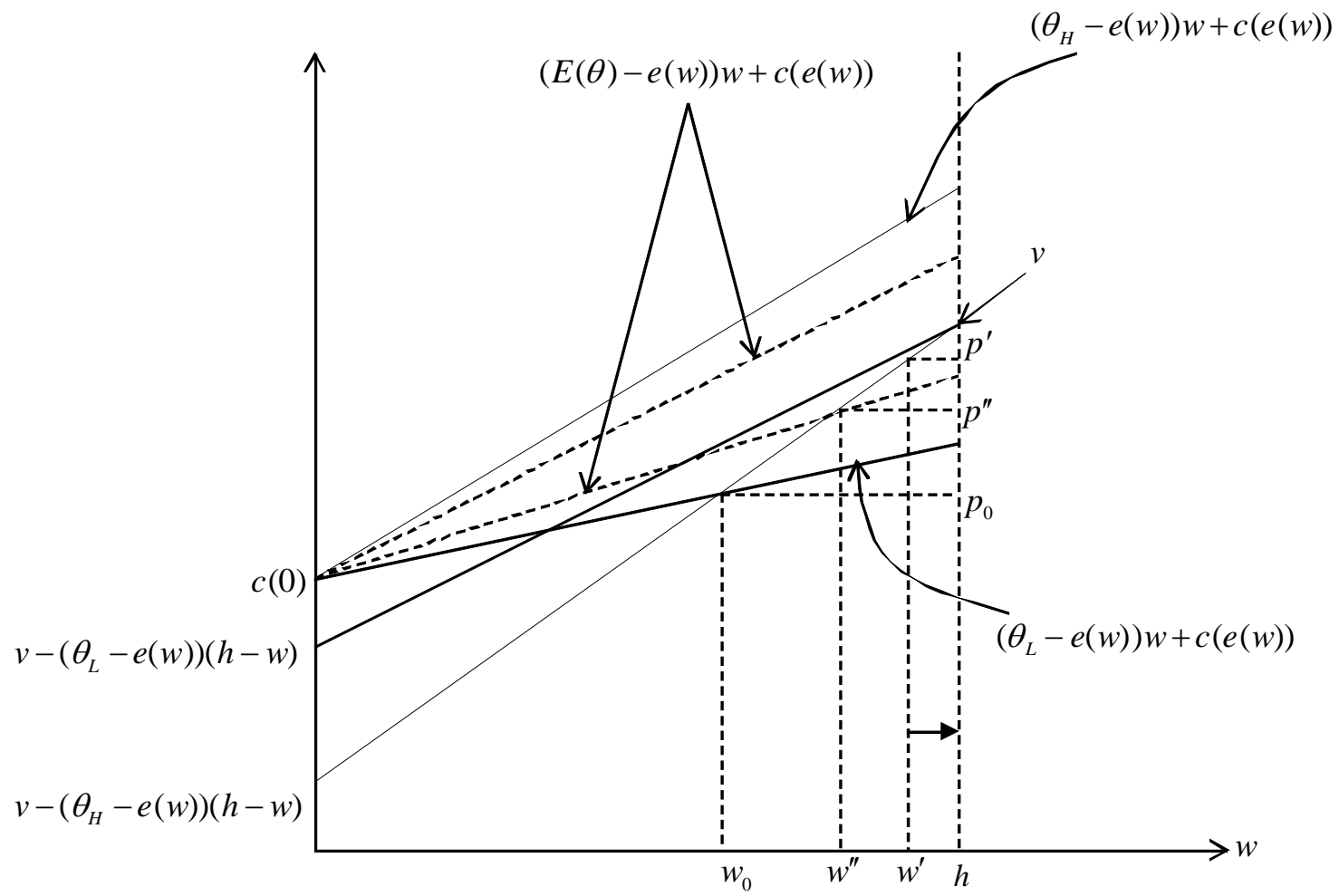

Figure 3: Optimal Social Policy when $\left(\theta_{H}-e^{*}\right) h+c\left(e^{*}\right)>v \geq\left(\theta_{L}-e^{*}\right) h+c\left(e^{*}\right)$ 
When the cost of serving both types is sufficiently low $\left(\left(\bar{\theta}-e^{*}\right) h+c\left(e^{*}\right)<v\right.$ and represented as the lower dotted diagonal line in Figure 3), keeping the high-risk consumers out of the market in a competitive equilibrium becomes more of a challenge. The reason is that whenever the mandated warranty gets close to the full level, because the average cost of serving both types will lie below both types' valuations, firms, in equilibrium, will have an incentive to offer a contract that attracts both types. To see this, from Figure 3 , whenever $w>w^{\prime \prime}$, under perfect competition, all firms will offer contract with price equal to the average cost of serving both types $(p=(\bar{\theta}-e(w)) w+c(e(w)))$ and attract both types of consumer. Attempting to serve only the low-risk consumers by charging a price above the high-type's valuation $\left(p \geq v-\left(\theta_{H}-e(w)\right)(h-w)\right)$ is strictly dominated since even the low-risk consumers will choose the contract with the lower price. When $\left(\bar{\theta}-e^{*}\right) h+c\left(e^{*}\right)<v$, therefore, the social planner can either (1) require firms to full warranty and allow both types of consumer to participate in the market or (2) mandate less-than-full warranty, sufficiently unattractive to the high-risk consumers, so that the firms will serve only the low-risk consumers.

If the full warranty were mandated, in a competitive market, firms will charge a price equal to the average cost $\left(p=\left(\bar{\theta}-e^{*}\right) h+c\left(e^{*}\right)\right)$, serve both types of consumer, and break even. Some transactional inefficiency will result from high-risk consumers participating in the market. Firms, however, will choose the optimal level of precaution $\left(e=e^{*}\right)$ : deterrence efficiency is achieved. When compared to the unregulated competitive equilibrium $\left(p_{0}, w_{0}\right)$, assuming its existence, the full warranty policy, unfortunately, does not guarantee welfare improvement. When firms were serving only the low-risk consumers but with incomplete warranty $\left(w_{0}<h\right)$, the inefficiency resulted from suboptimal deterrence $\left(e_{0}<e^{*}\right)$. When the fraction of high-risk consumers $(\pi)$ gets larger, the transactional inefficiency from serving them also grows. In contrast, the deterrence inefficiency in the unregulated competitive market gets smaller since there aren't as many low-risk consumers. The more high-risk consumers there are, therefore, the less attractive mandating full warranty becomes, making it uncertain whether the full warranty policy will improve upon the unregulated competitive outcome.

If the social planner were to keep the high-risk consumers out of the market, she must make sure that (1) the high-risk consumers find it unattractive to purchase the product and (2) firms will not have an incentive to deviate and serve both types of consumer. This is done by equating the cost of serving both types $((\bar{\theta}-e(w)) w+c(e(w)))$ with the high-risk consumers' valuation $\left(v-\left(\theta_{H}-e(w)\right)(h-w)\right)$, which is represented as $w^{\prime \prime}$ in Figure 3. With $w^{\prime \prime}$, firms will offer a price that is equal to (or slightly above) the high-risk consumers' valuation $\left(p^{\prime \prime}=v-\left(\theta_{H}-e\left(w^{\prime \prime}\right)\right)\left(h-w^{\prime \prime}\right)\right)$ and keep the high-risk consumers out. If a firm were to unilaterally deviate and price the product below $p^{\prime \prime}$, it will attract both types of consumer and make a negative profit. Pricing above $p^{\prime \prime}$ is also dominated since the firm will not be able to attract any consumers. Note that this is the best the social planner can do while keeping the high-risk consumers out. If she were to mandate a warranty level that exceeds $w^{\prime \prime}$, because the average cost now falls below both types' valuations, firms 
will serve both types of consumer at average cost. With $\left(w^{\prime \prime}, p^{\prime \prime}\right)$, each firm will enjoy a strictly positive profit margin but, due to free entry, will be infinitesimally small. Unlike the full warranty option, this policy strictly dominates the unregulated competitive equilibrium because firms are only serving the low-risk consumers but are spending more (while still at a suboptimal level) on safety precautions $\left(e_{0}<e^{\prime \prime}<e^{*}\right)$.

\section{Conclusion}

One of the important objectives of the products liability law is to create incentives for manufacturers to make cost-justified investments in product safety. Currently, the law attempts to achieve this objective by allowing harmed consumers to fully recover from the manufacturers and by prohibiting them from contractually waiving products liability. Such a rigid, mandatory imposition of liability has received much criticism. When the law allows consumers and manufacturers to privately stipulate almost every other aspect of the transaction, why not also allow them to choose their own liability regime, so long as they do so voluntarily and in an informed manner? The proponents of the "consumer sovereignty norm" have argued that the market-based system will not only function at a lower cost (especially when the current system is perceived to be so costly) but also better tailor to consumers' heterogeneous preferences over safety and liability. Firms will provide more extensive warranty, and correspondingly safer product, to those that are more prone to suffer harm (or more risk-averse), while for the others who are less likely to suffer harm (or less risk-averse), the market will offer products with less extensive warranty and a smaller number of safety attributes.

This paper has argued that when the market is subject to the problems of adverse selection, it will provide suboptimal safety incentive to firms. It is precisely the consumer heterogeneity (over propensity to suffer harm or risk-aversion) that causes the adverse selection and market failure. When firms cannot identify consumer type, in equilibrium, they will offer low-risk consumers products with suboptimal warranty and safety attributes. When the adverse selection problem is severe, the market may even completely fall apart, even though the consumers value the products more than the cost of producing them. To increase social welfare, the paper has argued that the social planner should consider either (1) requiring all firms to offer a full warranty, for instance, by prohibiting consumers from waiving products liability, or (2) mandating a warranty level that is less-than-full but provides better deterrence incentive to firms while keeping the very high-risk consumers from purchasing the product. In addition to providing better deterrence incentives to firms, the

policy can also restore a market equilibrium when the adverse selection problem led to a complete market break-down. 


\section{References}

[1] Abraham, K. The Forms and Functions of Tort Law. Westbury, New York: Foundation Press, 1997.

[2] Aghion, P. and Bolton, P. "Contracts as a Barrier to Entry." American Economic Review, Vol. 77 (1987), pp. 388-401.

[3] Aghion, P. and Hermalin, B. "Legal Restrictions on Private Contracts Can Enhance Efficiency." Journal of Law, Economics, and Organization, Vol. 6 (1990), pp. 381-409.

[4] Akerlof, G.A. "The Market for 'Lemons': Quality Uncertainty and the Market Mechanism." Quarterly Journal of Economics, Vol. 84 (1970), pp. 488-500.

[5] Arlen, J. "Contracting Over Liability: Medical Malpractice and the Cost of Choice." University of Pennsylvania Law Review, Vol. 158 (2010), pp. 101-167.

[6] Arlen, J. and MacLeod, W.B. "Malpractice Liability for Physicians and Managed Care Organizations." New York University Law Review, Vol. 78 (2003), pp. 1929-2006.

[7] Ausness, R.C. "'Waive' Goodbye to Tort Liability: A Proposal to Remove Paternalism from Product Sales Transactions." San Diego Law Review, Vol. 37 (2000), pp. 293-345.

[8] Besanko, D. and Thakor, A. "Collateral and Rationing: Sorting Equilibria in Monopolistic and Competitive Credit Markets." International Economic Review, Vol. 28 (1987), pp. 671-689.

[9] Bolton, P. and Dewatripont, M. Contract Theory. Cambridge, Massachusetts: MIT Press, 2005.

[10] Brown, J.P. "Toward an Economic Theory of Liability." Journal of Legal Studies, Vol. 2 (1973), pp. 323-349.

[11] Cooper, R. and Ross, T.W. "Product Warranties and Double Moral Hazard." RAND Journal of Economics, Vol. 2 (1985), pp. 101-113.

[12] Dari Mattiacci, G. and Parisi, F. "The Cost of Delegated Control: Vicarious Liability, Secondary Liability and Mandatory Insurance." International Review of Law and Economics, Vol. 23 (2004), pp. 453-475.

[13] Daughety, A.F. and Reinganum, J.F. "Product Safety: Liability, R\&D, and Signaling." American Economic Review, Vol. 85 (1995), pp. 1187-1206.

[14] Daughety, A.F. and Reinganum, J.F. "Everybody Out of the Pool: Products Liability, Punitive Damages, and Competition." Journal of Law, Economics and Organization, Vol. 13 (1997), pp. 410-432. 
[15] Daughety, A.F. and Reinganum, J.F. "Communicating Quality: a Unified Model of Disclosure and Signaling." RAND Journal of Economics, Vol. 39 (2008), pp. 973-989.

[16] Dybvig, P.H. and Lutz, N.A. "Warranties, Durability, and Maintenance: Two-Sided Moral Hazard in a Continuous Time Model." Review of Economic Studies, Vol. 60 (1993), pp. 575-598.

[17] Epple, D. and Raviv, A. "Product Safety: Liability Rules, Market Structure, and Imperfect Information." American Economic Review, Vol. 68 (1978), pp. 80-95.

[18] Epstein, R.A. "Medical Malpractice: The Case For Contract." American Bar Foundation Research Journal, Vol. 1 (1976), pp. 87-149.

[19] Fudenberg, D. and Tirole, J. "Moral Hazard and Renegotiation in Agency Contracts." Econometrica, Vol. 58 (1990), pp. 1279-1319.

[20] Geistfeld, M. "Manufacturer Moral Hazard and the Tort-Contract Issue in Products Liability." International Review of Law and Economics, Vol. 15 (1995), pp. 241-257.

[21] Grossman, S.J. "Informational Role of Warranties and Private Disclosure about Product Quality." Journal of Law \& Economics, Vol. 24 (1981), pp. 461-483.

[22] Hamada, K. "Liability Rules and Income Distribution in Product Liability." American Economic Review, Vol. 66 (1976), pp. 228-234.

[23] Hay, B. and Spier, K. "Manufacturer Liability for Harms Caused by Consumers to Others." American Economic Review, Vol. 95 (2005), pp. 1700-1711.

[24] Heal, G. "Guarantees and Risk Sharing." Review of Economic Studies, Vol. 44 (1977), pp. 549-560.

[25] Kessler, F. "Contracts of Adhesion-Some Thoughts about Freedom of Contract." Columbia Law Review, Vol. 43 (1943), pp. 629-642.

[26] Klein, B. and Leffler, K.B. "The Role of Market Forces in Assuring Contractual Performance." Journal of Political Economy, Vol. 89 (1981), pp. 615-641.

[27] Kubo, Y. "Quality Uncertainty and Guarantee-A Case of Strategic Market Segmentation by a Monopolist." European Economic Review, Vol. 30 (1986), pp. 1063-1079.

[28] Lutz, N. "Warranties as Signals Under Consumer Moral Hazard." RAND Journal of Economics, Vol. 20 (1989), pp. 239-255.

[29] Lutz, N. and Padmanabhan, V. "Why Do We Observe Minimal Warranties?" Marketing Science, Vol. 14 (1995), pp. 417-440.

[30] Lutz, N. and Padmanabhan, V. "Warranties, Extended Warranties, and Product Quality." International Journal of Industrial Organization, Vol. 16 (1998), pp. 463-493. 
[31] Matthews, S. and Moore, J. "Monopoly Provision of Quality and Warranties - An Exploration in the Theory of Multidimensional Screening." Econometrica, Vol. 55 (1987), pp. 441-467.

[32] Oi, W. "The Economics of Product Safety." Bell Journal of Economics and Management Science, Vol. 4 (1973), pp. 3-28.

[33] Ordover, J.A. "Products Liability in Markets with Heterogeneous Consumers." Journal of Legal Studies, Vol. 8 (1979), pp. 505-525.

[34] Padmanabhan, V. "Usage Heterogeneity and Extended Service Contracts." Journal of Economics and Management Strategy, Vol. 4 (1995), pp. 33-53.

[35] Polinsky, A.M. and Rogerson, W.P. "Products Liability, Consumer Misperceptions, and Market Power." Bell Journal of Economics, Vol. 14 (1983), pp. 581-589.

[36] Polinsky, A. and Shavell, S. "The Uneasy Case for Product Liability." Harvard Law Review, Vol. 123 (2010), pp. 1437-1492.

[37] Priest, G. "A Theory of the Consumer Product Warranty." Yale Law Journal, Vol. 90 (1981), pp. 1297-1352.

[38] Priest, G. "The Modern Expansion of Tort Liability: Its Sources, Its Effects, and Its Reform." Journal of Economic Perspectives, Vol. 5 (1991), pp. 31-50.

[39] Riley, J.G. "Information, Screening, and Human Capital." American Economic Review, Vol. 66 (1976), pp. 254-260.

[40] Rothschild, M. and Stiglitz, J. "Equilibrium in Competitive Insurance Markets: An Essay on the Economics of Imperfect Information." Quarterly Journal of Economics, Vol. 90 (1976), pp. 629-649.

[41] Schwartz, A. "Proposals for Products Liability Reform: A Theoretical Synthesis." Yale Law Journal, Vol. 97 (1988), pp. 353-419.

[42] Schwartz, A. "The Case Against Strict Liability." Fordham Law Review, Vol. 60 (1992), pp. 819-842.

[43] Spence, M. "Consumer Misperceptions, Product Failure and Producer Liability." Review of Economic Studies, Vol. 44 (1977), pp. 561-572.

[44] Spier, K.E. "A Note on the Divergence Between the Private and the Social Motive to Settle under a Negligence Rule." Journal of Legal Studies, Vol. 26 (1997), pp. 613-621.

[45] Spier, K.E. and Whinston, M.D. "On the Efficiency of Privately Stipulated Damages for Breach of Contract: Entry Barriers, Reliance, and Renegotiation." RAND Journal of Economics, Vol. 26 (1995), pp. 180-202. 
[46] Sykes, A.O. "Vicarious Liability." In P. Newman, ed., The New Palgrave Dictionary of Economics and the Law. New York, NY: Palgrave MacMillan, 1998.

[47] Wickelgren, A.L. "The Inefficiency of Contractually Based Liability with Rational Consumers." Journal of Law, Economics, $\&$ Organization, Vol. 22 (2006), pp. 168-183.

[48] Wilson, C. "A Model of Insurance Markets with Incomplete Information." Journal of Economic Theory, Vol. 16 (1977), pp. 167-207. 